Research Article

\title{
Depleted lherzolite xenoliths from the leucititic Morrón de Villamayor volcano (Calatrava volcanic field, Spain)
}

\author{
Javier García Serrano ${ }^{\mathrm{a}, *}$, Carlos Villaseca a,b, Cecilia Pérez-Soba ${ }^{\text {a }}$ \\ a Departamento de Mineralogía y Petrología, Facultad de Ciencias Geológicas, Universidad Complutense de Madrid, C/José Antonio Novais 12, 28040 Madrid, Spain \\ b Instituto de Geociencias IGEO (UCM, CSIC), C/Doctor. Severo Ochoa 7, 28040 Madrid, Spain
}

\section{A R T I C L E I N F O}

\section{Article history:}

Received 15 April 2020

Received in revised form 1 October 2020

Accepted 9 October 2020

Available online 18 October 2020

\section{Keywords:}

Lherzolite xenoliths

Leucitite magma

Alkaline metasomatism

Xenolith-host melt interaction

Calatrava Volcanic Field

\begin{abstract}
A B S T R A C T
This work reports petrographical, mineralogical and geochemical data of a suite of mantle xenoliths from the Morrón de Villamayor volcanic centre (MVM), which belongs to the Calatrava Volcanic Field (CVF), a part of the Circum-Mediterranean Anorogenic Cenozoic Igneous Province. The MVM volcano is the only centre belonging to the first stage of the CVF magmatism, an ultrapotassic stage that provides a sampling of the subcontinental lithospheric mantle beneath central Spain. The MVM peridotites record a variable host melt interaction (spongy texture and reaction zones), more intense toward xenolith-host leucitite contacts that it was formed during transport within the volcanic melt. The studied mantle xenoliths are spinel lherzolites equilibrated at lower temperatures (618-942 ${ }^{\circ} \mathrm{C}$ ) and similar pressure ranges (8.8-13.6 kbar) than other studied CVF mantle xenoliths, and record a lithospheric mantle before the main volcanic Calatrava event. The MVM lherzolites could be classified in two groups by their chondrite-normalized rare earth element (REE) clinopyroxene patterns: group-1 lherzolites show flat pattern, and group-2 lherzolites display a LREE-depleted (N-MORB like) pattern. Group-1 lherzolites represent a more residual lithospheric mantle (up to 9 partial melting \%) than group-2 lherzolites $(\sim 5 \%)$, the latter with similar partial melting degrees than other mantle xenoliths from the CVF. Moreover, group- 1 lherzolites have undergone a post partial melting refertilization by different metasomatic agents: silicate and alkaline silicate melts different in composition to host leucitite. A primary clinopyroxene concentrate from these MVM lherzolites provides high $\mathrm{Sr}\left({ }^{87} \mathrm{Sr} /{ }^{86} \mathrm{Sr}=0.706104\right)$ and intermediate $\mathrm{Nd}\left({ }^{143} \mathrm{Nd} /{ }^{144} \mathrm{Nd}=0.512830\right)$ initial radiogenic ratios, not previously recorded in this volcanic field. This sampling proves the presence of an enriched isotope mantle pole in xenolith suites of the Calatrava area, trending in composition to an intermediate DMM-EMII component.
\end{abstract}

(C) 2020 Elsevier B.V. All rights reserved.

\section{Introduction}

Peridotite xenoliths exhumed by Cenozoic alkaline volcanoes are an essential source of information about the nature and evolution of the subcontinental lithospheric mantle (e.g., Downes, 2001). In the Iberian Peninsula there are four main Cenozoic volcanic fields that contain significant mantle xenoliths suites: SE Spain (Avanzinelli et al., 2020; Beccaluva et al., 2004), Olot (Bianchini et al., 2007; Galán et al., 2008), Levante (Seghedi et al., 2002) and Calatrava (Ancochea and Nixon, 1987).

Previous studies of the mantle xenoliths in the Calatrava volcanic field (CVF) have focused in the volcanic centres of El Aprisco (González-Jimenez et al., 2014; Lierenfeld and Mattsson, 2015; Puelles et al., 2016; Villaseca et al., 2010; Villaseca et al., 2019a), Los Tormos (Andía, 2017; Andía et al., 2018), Cerro Gordo (Villaseca et al., 2019c)

\footnotetext{
* Corresponding author at: J. Dpto. Mineralogía y Petrología, Facultad de Ciencias Geológicas, Universidad Complutense de Madrid, C/José Antonio Novais 12, 28040 Madrid, Spain.

E-mail address: jgserrano@ucm.es (J. García Serrano).
}

and El Palo (Bianchini et al., 2010). The peridotite xenoliths from the volcano Morrón de Villamayor (MVM) have been only preliminarily studied (García Serrano et al., 2019), although their host leucitite volcanic rocks have been the subject of detailed studies (e.g., Humphreys et al., 2010; Lustrino et al., 2016).

In this work, we characterize the mantle beneath the MVM volcano distinguishing host melt interaction from metasomatic processes occurring at mantle depths. The ultrapotassic nature of the host magma compared to the sodic-alkaline nature of the rest of the CVF volcanic rocks, and its older eruptive age $(7.4 \pm 1 \mathrm{Ma})$ compared with the more recent ages of the rest of the Calatrava volcanoes (3.7-0.7 Ma) (Ancochea, 2004) provides a mantle sampling that record different mantle conditions, partial fusion processes and metasomatic events. Mantle xenoliths are generally assumed to have been rapidly transported to the surface, with little or no alteration of the primary mineralogy (O'Reilly and Griffin, 2010), but even so, there are abundant reaction zones in the studied samples that evidence host melt interaction in a stronger degree than in other studied xenolith suites from the CVF (Andía et al., 2018; Bianchini et al., 2010; Villaseca et al., 2010). We have distinguished textures that are of ancient mantle origin versus those imposed 
on the xenoliths during magma transport or residence period (Shaw et al., 2006). Therefore, the aim of this study is to assess host melt interaction, metasomatic events and $P-T$ conditions to characterize this subcontinental lithospheric mantle sector compared to other mantle xenoliths of the CVF. With this purpose, major and trace element whole-rock and mineral compositions of MVM mantle xenoliths and the host leucitite have been obtained, including $\mathrm{Nd}$ and $\mathrm{Sr}$ isotope ratios.

\section{Geological setting}

Alkaline and subalkaline mafic magmas erupted in different regions of western and central Europe during the Cenozoic, defining the Circum-Mediterranean Anorogenic Cenozoic Igneous Province (CiMACI; Lustrino and Wilson, 2007). The CVF represents an anorogenic intracontinental alkaline magmatic zone formed in Neogene time within the CiMACI. This volcanic field is located at the western termination of the SSW-NNE tectonic basin of the Guadiana River (Fig. 1), bordered to the north-west by the Toledo Mountains. The CVF was constructed over a Paleozoic basement later uplifted during the Alpine orogeny (De Vicente and Vegas, 2009; López Ruiz et al., 2002). The volcanic vents distribution of the CVF is mainly conditioned by Variscan shear bands reactivated by the Betic collision (Cebriá et al., 2011). The geodynamic setting of the Calatrava volcanism is still controversial, with the debate focussed on four main models: (1) volcanic clustering related to asthenospheric-mantle upwelling (hot spots or diapiric instabilities) in a pre-rifting stage (Ancochea and Brändle, 1982; López Ruiz et al., 1993); (2) a megafault system affecting the western Mediterranean European block (López Ruiz et al., 2002); (3) the reactivation of previous NW-SE fractures during the extensional regime induced by the accretion of the Betic ranges (Cebriá et al., 2011); (4) mantle instabilities in a back-arc position during the roll-back of the Alboran slab (Carminati et al., 2012; Granja Bruña et al., 2015).

The CVF is exclusively formed by monogenetic volcanic centres, suggesting small and short-lived magma chambers. This volcanic field consists of approximately 250 volcanic centres in an area of around $5500 \mathrm{~km}^{2}$. The main eruption centres are NNW-SSE aligned, generally following the preferential directions of N135-150E, N40E and N80-85E (Ancochea, 2004; Cebriá et al., 2011). Most edifices are strombolian cones although more than 50 tuff rings and maars, and scarce lava flows, have also been described. Peridotite xenoliths appear in a scarce number of these three types of volcanoes. The volcanic activity of the CVF begun in the Late Miocene, defining two different stages. The first stage was a minor ultrapotassic event around $7.4 \pm 1 \mathrm{Ma}$ ago, forming the leucititic MVM volcanic centre, the focus of this study. The main stage was dominated by alkaline basanites, olivine nephelinites and melilitites from 3.7 to 0.7 Ma (Ancochea, 1982, 2004; HerreroHernández et al., 2015; Villaseca et al., 2019a).

The MVM volcano is a very small $\left(<1 \mathrm{~km}^{2}\right)$ monogenetic volcanic edifice cropping out in the western sector of the CVF (Fig. 1). The outcrop consists of a set of variable porphyritic olivine leucitite lava flows showing large olivine macrocrysts. Columnar jointing through the lava flows indicates that they form two cooling units. The peridotite xenoliths are scarce, showing small-size ( $<7 \mathrm{~cm}$ in maximum length) and thin tabular shape $(<1.5 \mathrm{~cm}$ in thickness), with a variable host meltinteraction degree.

\section{Analytical methods}

Fourteen peridotite xenoliths and two host leucitite samples from the MVM volcano were selected for this study. Modal xenolith

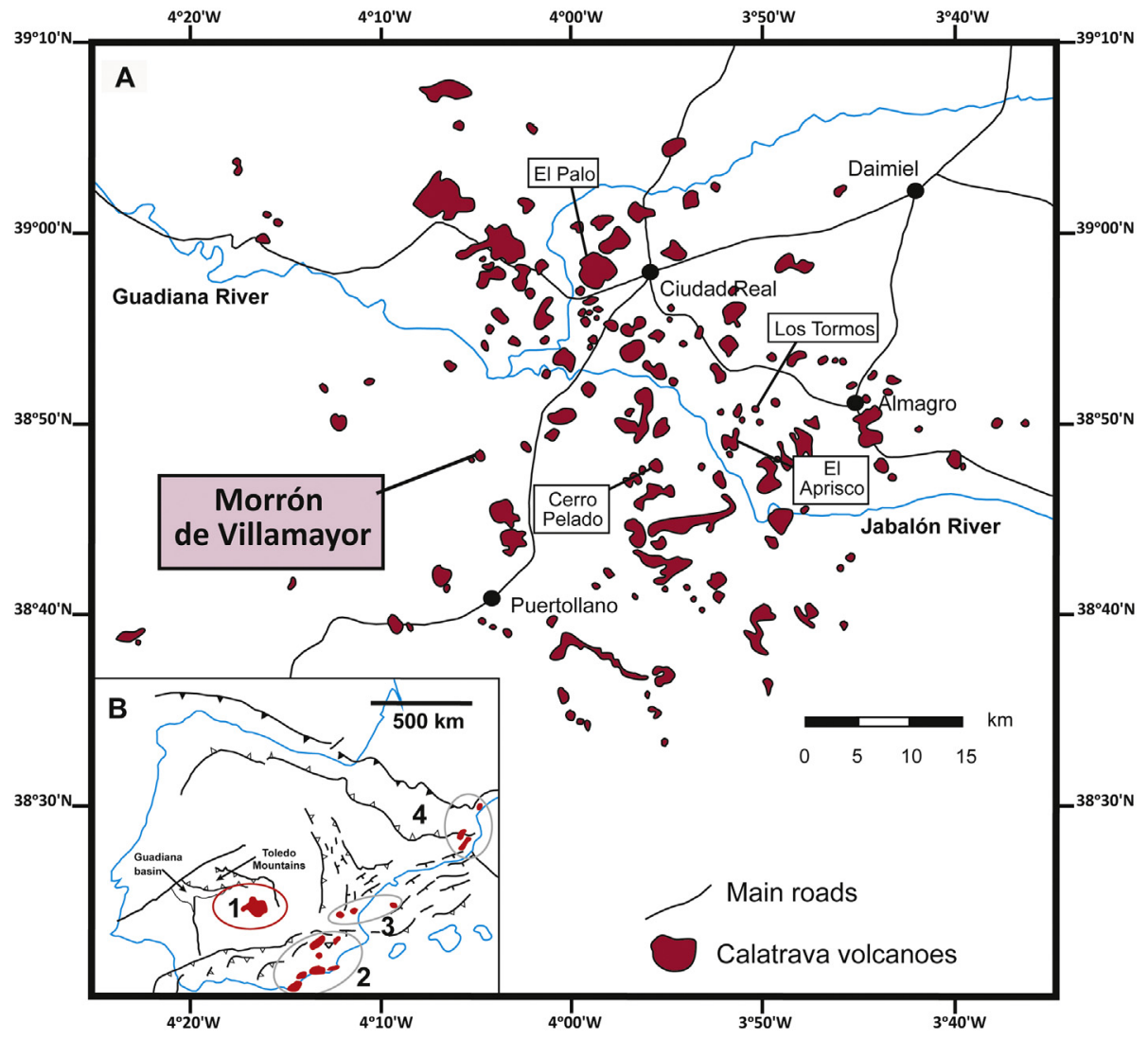

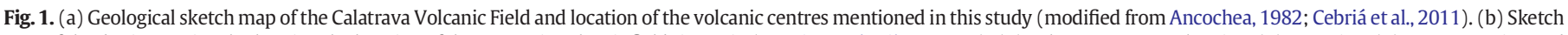

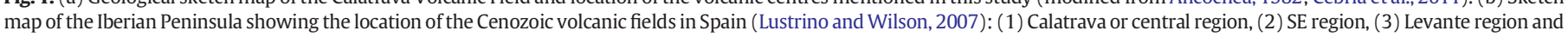
(4) Olot or NE region. 
composition was estimated by point-counting (1575-714 points per thin section, Table 1) and complemented by mass balance estimates from those samples with whole-rock and mineral chemical analyses (Albaréde, 1995). A problem with mantle xenoliths is to realize if the counting surface is representative, due to the xenolith small size and orientation (foliation) presented by some lherzolites that could generate a significant analytical error. Moreover, in the largest MVM xenoliths, thin sections were prepared at xenolith edges in order to obtain the maximum size for whole-rock analysis, leading to an overestimation of reaction zones and host-melt interaction.

Major element mineral composition was analysed at the Centro Nacional de Microscopía Electrónica (Complutense University of Madrid) using a Jeol JXA-8900 M electron microprobe with four wavelength dispersive spectrometers. Analytical conditions were an accelerating voltage of $15 \mathrm{kV}$ and an electron beam current of $20 \mathrm{nA}$, with a beam diameter of $5 \mu \mathrm{m}$. Elements were counted for $10 \mathrm{~s}$ on the peak and $5 \mathrm{~s}$ on each background position. Corrections were made using an online ZAF method. Detection limits are 0.02 wt\% for Al, Na, K, and P; 0.03 wt\% for Ti, Fe, Mn, Mg; Ni and $\mathrm{Cr}$; and 0.04 wt\% for $\mathrm{Si}$.

We have determined the in situ concentrations of 30 trace elements

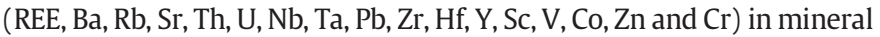
grains on $>90 \mu \mathrm{m}$-thick polished sections using laser ablation (LA-ICPMS) at the Instituto Andaluz de Ciencias de la Tierra (CSIC) of Granada, using an Agilent 8800 QQQ ICP-MS coupled to a Photon Machines Analyte Excite 193 laser source. The diameter of the laser beam was 40 to $85 \mu \mathrm{m}$ (depending on the mineral size) associated to repetition rates of $10 \mathrm{~Hz}$ and laser fluence at the target of ca. $8 \mathrm{~J} / \mathrm{cm}^{2}$. A 40-30 s gas blank was analysed first to establish the background, followed by $60 \mathrm{~s}$ measurements for the remainder of the analysis. The NIST 611 glass standard was used as primary reference material to calibrate relative element sensitivities for analyses of the silicate minerals. Precision and accuracy were assessed from repeated analyses of the USGS-BIR 1G standard and are estimated to be between $2 \%$ and $10 \%$ for most of the

Table 1

Modal composition and textural features of the Morrón de Villamayor peridotite xenoliths.

\begin{tabular}{|c|c|c|c|c|c|c|c|}
\hline \multirow[t]{2}{*}{ Sample } & \multirow[t]{2}{*}{ Texture } & \multicolumn{5}{|c|}{$\begin{array}{l}\text { Calculated modal } \\
\text { abundances (vol\%) }\end{array}$} & \multirow[b]{2}{*}{$\begin{array}{l}\text { r.z. } \\
\text { (vol\%) }\end{array}$} \\
\hline & & $\mathrm{Ol}$ & Opx & Cpx & Sp & $\mathrm{n}$ & \\
\hline \multicolumn{8}{|l|}{ Group 1} \\
\hline 116352 & Coarse grained-protogranular & 65 & 18 & 16 & 2 & 1125 & 8.9 \\
\hline $116352^{\mathrm{mb}}$ & Coarse grained-protogranular & 58 & 27 & 12 & 3 & - & - \\
\hline 116442 & Coarse grained-protogranular & 57 & 17 & 26 & - & 896 & 5.0 \\
\hline \multicolumn{8}{|l|}{ Group 2} \\
\hline 116351 & $\begin{array}{l}\text { Fine grained-equigranular, } \\
\text { foliated }\end{array}$ & 65 & 20 & 10 & 5 & 818 & 12.3 \\
\hline $116428^{*}$ & Coarse grained-protogranular & 45 & 20 & 27 & 9 & 1076 & 9.0 \\
\hline $116429^{*}$ & Coarse grained-protogranular & 47 & 28 & 21 & 4 & 714 & 15.7 \\
\hline 116430 & Coarse grained-protogranular & 60 & 23 & 13 & 5 & 874 & 20.8 \\
\hline $116431^{*}$ & Coarse grained-protogranular & 49 & 18 & 25 & 8 & 1244 & 14.8 \\
\hline 116433 & Coarse grained-protogranular & 55 & 21 & 21 & 4 & 1239 & 21.1 \\
\hline 116434 & Coarse grained-protogranular & 54 & 20 & 21 & 6 & 1318 & 7.1 \\
\hline 116435 & Coarse grained-protogranular & 56 & 21 & 19 & 5 & 740 & 9.2 \\
\hline $116435^{\mathrm{mb}}$ & Coarse grained-protogranular & 66 & 17 & 16 & 2 & - & - \\
\hline 116436 & Coarse grained-protogranular & 56 & 21 & 17 & 7 & 846 & 3.2 \\
\hline $116436^{\mathrm{mb}}$ & Coarse grained-protogranular & 68 & 20 & 11 & 1 & - & - \\
\hline $116440^{\mathrm{mb}}$ & Coarse grained-Protogranular & 73 & 8 & 15 & 4 & - & - \\
\hline 117174 & $\begin{array}{l}\text { Fine grained-seried } \\
\text { equigranular, slightly foliated }\end{array}$ & 51 & 23 & 21 & 5 & 1575 & 10.6 \\
\hline 117183 & $\begin{array}{l}\text { Fine grained-seried } \\
\text { equigranular }\end{array}$ & 60 & 17 & 20 & 4 & 842 & 9.4 \\
\hline $117183^{\mathrm{mb}}$ & $\begin{array}{l}\text { Fine grained-seried } \\
\text { equigranular }\end{array}$ & 65 & 19 & 14 & 2 & - & - \\
\hline
\end{tabular}

Ol: olivine; Opx: orthopyroxene; Cpx: clinopyroxene; Sp: spinel. n: number of points in the modal counting; $m b$ : modal estimation by mass-balance from chemical analyses (Albaréde, 1995).

* Large cpx crystals (up to $5 \mathrm{~mm}$ ).

** Reaction zones. analysed trace elements. Each analysis was normalized to $\mathrm{Si}$ or $\mathrm{Ca}$ using concentrations determined by electron microprobe.

The whole-rock major and trace element composition for six spinel lherzolite xenoliths and two host olivine leucitite rocks were analysed at ACTLABS. Whole-rock chemical analysis of these thin and small sized xenoliths poses a challenge as it is not easy to avoid host melt contamination, given the difficulty to discern by eye the incoming of volcanic material (small veinlets and reaction zones) into the crushed material. As we will show below, some minor contamination in samples is indicated by critical elements (LILE and LREE, due to the nature of the host leucitite melt) and accordingly discussed. Two analysed lherzolites (116440 and 117184) show a strong host melt interaction, but we included these two samples in some diagrams and tables to observe the contamination consequences. Samples were melted using $\mathrm{LiBO}_{2}$ and dissolved with $\mathrm{HNO}_{3}$. The solutions were analysed by inductively coupled plasma atomic emission spectrometry (IACP-AES) for major elements, whereas trace elements were determined by ICP mass spectrometry (ICP-MS). Uncertainties in major elements are bracketed between 1 and 3\% except $\mathrm{Mn}(5-10 \%)$ and $\mathrm{P}_{2} \mathrm{O}_{5}(>10 \%)$. The precision of ICP-MS analyses at low concentration levels was evaluated from repeated analyses of the international standards BR, DR-N, UB-N, AN-G and $\mathrm{GH}$. The precision for $\mathrm{Rb}, \mathrm{Sr}, \mathrm{Zr}, \mathrm{Y}, \mathrm{V}, \mathrm{Hf}$ and most of REE were in the range $1-5 \%$, whereas they range from 5 to $10 \%$ for the rest of trace elements, including $\mathrm{Tm}$. Some samples have concentrations of certain elements below detection limits $\left(\mathrm{K}_{2} \mathrm{O} 0.01 \%\right.$; $\mathrm{Rb} 1 ; \mathrm{Zr} 1 ; \mathrm{Nb} 0.2 ; \mathrm{Tb}$ 0.01; Ho 0.01; Tm 0.005; Lu 0.002; Hf 0.01; Ta 0.01; Th 0.05; U 0.01). More information on the procedure, precision and accuracy of ACTLABS ICP-MS analyses is available at www.actlabs.com.

$\mathrm{Sr}-\mathrm{Nd}$ isotope ratios were measured on five mantle xenoliths and one separate of primary clinopyroxene crystals handpicked from two coarse-grained protogranular lherzolites with large clinopyroxenes (sample 116429). The study of unmodified original Sr-Nd isotopic signature of MVM lherzolites recorded from the clinopyroxene separate is crucial for comparison purposes with later mantle sampling made by Na-rich alkaline Calatrava volcanoes. The MVM lherzolites, the mineral separate and two host leucitite samples were analysed at the CAI de Geocronología y Geoquímica Isotópica of the Complutense University of Madrid, using an automated Phoenix-IsotopX Multicollector thermal ionization mass spectrometer with data acquired in multidynamic mode. Whole-rock samples and the clinopyroxene separate were dissolved in ultra-pure reagents and the isotopes were subsequently isolated by exchange chromatography. The analytical procedures used in this laboratory are described elsewhere (Reyes et al., 1997). Repeated analyses on the NBS-987 standard gave ${ }^{87} \mathrm{Sr} /{ }^{86} \mathrm{Sr}=0.710240 \pm$ $0.00005(2 \sigma, n=8)$ and for the La Jolla standard, values of the ${ }^{143} \mathrm{Nd} /{ }^{144} \mathrm{Nd}=0.511847 \pm 0.00003(2 \sigma, n=14)$ were obtained. The $2 \sigma$ internal analytical errors are $0.01 \%$ for ${ }^{87} \mathrm{Sr} /{ }^{86} \mathrm{Sr}$ and $0.006 \%$ for ${ }^{143} \mathrm{Nd} /{ }^{144} \mathrm{Nd}$.

\section{Results}

\subsection{Petrography}

\subsubsection{Host olivine leucitite}

The olivine leucitite lava flows usually show highly porphyritic texture with olivine, and more rarely clinopyroxene, macrocrysts (up to $7 \mathrm{~mm}$ ). The aphanitic groundmass is composed of olivine, clinopyroxene, leucite, phlogopite/biotite, nepheline, apatite and titanomagnetite. Olivine macrocrysts compose up to 30 modal\% of some of the leucitite lava samples and it is commonly well preserved (except some altered iddingsite thin rims). This olivine is subeuhedral and commonly fractured, often containing pseudo-inclusions of carbonate as secondary vesicle and fracture infillings with clinopyroxene and other groundmass phases. A more detailed petrographic description of the MVM leucitites is in Lustrino et al. (2016). 


\subsubsection{Peridotite xenoliths}

Within the volcanic rock, centimetre-sized mantle xenoliths appear. They show different compositional and textural features. Xenoliths display a coarse- to medium-grained protogranular texture, except three samples that present small-grained equigranular texture (Table 1). As observed in mantle xenoliths from the El Aprisco volcanic centre (Puelles et al., 2016), some of the studied peridotite thin sections (especially those of small-grained texture) show oriented microstructures (foliation and banding) since grain shapes are significantly elongated, contributing to the macroscopic rock foliation definition. This orientation could have influenced the small thickness and the slice or lamellar shape of the MVM xenoliths. Other xenoliths from the CVF also show systematic shape-preferred orientations (banding, foliation or macroscopic lineation) (e.g., Puelles et al., 2016) and common deformation microstructures (undulose extinction in pyroxenes and subgrains in olivine) (e.g., Andía, 2017; Villaseca et al., 2010). The current scarce petrofabric studies on CVF peridotite xenoliths do not suggest the existence of non-deformed subcontinental lithospheric mantle domains in central Iberia, rather the contrary, they exhibit heterogeneous mantle fabrics strongly dependent of the original nature of the mantle protolith and the subsequent interaction with metasomatic agents (Puelles et al., 2016). Thus, no significant differences in deformation between xenolith suites from the CVF are discernible with the current data.

Modal analyses (Table 1) indicate that the MVM peridotite xenoliths are lherzolites, similarly to most studied CVF xenoliths (Supplementary Fig. S1), although with less compositional variety due to the absence of associated wehrlite or harzburgite types (Andía et al., 2018; Villaseca et al., 2010).

The MVM lherzolites consist of olivine, clinopyroxene, orthopyroxene, spinel and secondary minerals from the reaction zones with the host magma (Figs. 2a and b). Modal hydrous metasomatic minerals have not been found. Olivine grain boundaries vary from curvilinear to straight with common $120^{\circ}$ triple junctions with clinopyroxene. Orthopyroxene grains are usually larger than clinopyroxene, except in 116428 and 116431 lherzolites, where clinopyroxene appears as big crystals (up to $0.5 \mathrm{~cm}$ ) (Table 1). Spinel grains occur in a wide size range (up to $2 \mathrm{~mm}$ ), as isolated globular to anhedral crystals occupying interstitial position between rock-forming minerals, and characteristic holly-leaf forms (Fig. 2c).

Some of these xenoliths display large reaction zones with the surrounding volcanic groundmass (up to 21 modal\%, Table 1), in a higher degree than those observed in other CVF xenolith suites (Andía et al., 2018; Bianchini et al., 2010; Villaseca et al., 2010). Locally, orthopyroxene has thick reaction rims, similar to those observed in many peridotite xenoliths hosted in alkaline melts (e.g. Marchev et al., 2017; Shaw et al., 1998). The thickness of the reaction zone (and the size of neoformed secondary minerals) decreases systematically from the contact to the inner part of the xenolith. Reaction zones are characterized by fine-grained aggregates of secondary minerals (Fig. 2): amphibole (richterite) (Fig. 2a), rounded olivine (Fig. 2d), clinopyroxene as oriented rods (Fig. 2d), interstitial sanidine (Fig. 2d) and carbonate patches, similar to those studied by Lustrino et al. (2016). Spongytextured clinopyroxene and spinel crystals also increase toward the xenolith margins. This spongy texture appears at crystal rims and along crystal microfractures but even as full (pseudomorphosed) crystals. The spongy clinopyroxene has a cellular morphology filled by microinclusions of secondary minerals (leucite, nepheline, olivine, sulphides and apatite) and vugs, similar to that described by Pan et al. (2018) (Figs. 2e and f). Spongy texture in spinel occurs as thin rims or by complete replacement by spongy chromite, developing finergrained secondary spinel crystals (Fig. 2f).

\subsection{Mineral chemistry}

The MVM mantle xenoliths consist of variable proportions of olivine, clinopyroxene, orthopyroxene, aluminous spinel, and secondary minerals, whose compositions are summarized in Supplementary Table S1. Major element mineral compositions are compared to others previously studied CVF mantle xenoliths: El Palo (Bianchini et al., 2010), Cerro Pelado (Villaseca et al., 2010) and mainly with El Aprisco group-4 lherzolites (González-Jimenez et al., 2014; Villaseca et al., 2010). The other El Aprisco mantle xenoliths groups (nomenclature after González-Jimenez et al., 2014) define a wide compositional variety. According to clinopyroxene major and trace element chemical compositions, two groups of MVM lherzolite xenoliths are distinguished: group-1, characterized by Ti-Al-poor clinopyroxene with flat chondrite-normalized REE patterns, and group-2 having Ti-Al-rich clinopyroxene, showing chondrite-normalized LREE-depleted (NMORB like) patterns.

\subsubsection{Major element mineral composition}

Primary olivine of MVM lherzolites has an homogeneous composition and a narrow $\mathrm{Mg} \#\left[\left(100 \times \mathrm{Mg}^{2+} /\left(\mathrm{Mg}^{2+}+\mathrm{Fe}^{2+}\right)\right.\right.$ on a molecular basis] range (89.4-91.2), similar to those from the El Aprisco (90.0-91-2) and the Cerro Pelado (89.4-90.6) (Villaseca et al., 2010), and higher than those from the El Palo (84.9-89.6) lherzolites (Bianchini et al., 2010) (Fig. 3a). NiO content is slightly lower than in El Palo lherzolites (Bianchini et al., 2010), but similar to those from the El Aprisco group-4 and Cerro Pelado lherzolites (Villaseca et al., 2010) (Fig. 3a). The Mg\# values of the MVM olivine are slightly lower in the group-2 (89.7-90.9) than in the group-1 (90.1-92.1) (Fig. 3a). Primary olivine shows higher $\mathrm{NiO}$ and slightly higher $\mathrm{CaO}$ contents than secondary olivine, while this latter shows wider Mg\# range (86.4-92.8) than the primary.

Orthopyroxene (enstatite) shows Mg\# ranging from 89.5 to 91.2, although those from the group-1 may reach higher Mg\# values (up to 92.7) (Fig. 3b). These values are slightly higher than those in the El Aprisco group-4 and Cerro Pelado lherzolites (Villaseca et al., 2010), and markedly higher than those in the El Palo samples (Bianchini et al., 2010). Orthopyroxene from the group-1 lherzolites displays higher $\mathrm{Cr}_{2} \mathrm{O}_{3}$ and lower $\mathrm{Al}_{2} \mathrm{O}_{3}$ contents compared with the group-2 peridotites. Additionally, orthopyroxene in studied MVM peridotite xenoliths shows a wide range in $\mathrm{CaO}(0.15-1.92 \mathrm{wt} \%)$ content (Supplementary Table S1), which is typical of abyssal peridotites (Bonatti and Michael, 1989).

Primary clinopyroxene (diopside) from group-1 lherzolites has higher Mg\# (90.7-94.0) and lower $\mathrm{Al}_{2} \mathrm{O}_{3}$ (4.64-6.14 wt\%), $\mathrm{Na}_{2} \mathrm{O}$ (1.11-1.48 wt\%) and $\mathrm{TiO}_{2}(0.07-0.24 \mathrm{wt} \%)$ contents than in group-2 (5.80-7.75 wt\%, 1.15-1.89 wt\% and $0.30-0.53$ wt\%, respectively) (Fig. 4a and b). As shown by the other mafic minerals, clinopyroxene Mg\# is slightly higher than in the El Aprisco group-4 lherzolites, and remarkably higher than those in the Cerro Pelado and El Palo lherzolites (Villaseca et al., 2010). Secondary clinopyroxene shows lower $\mathrm{Al}_{2} \mathrm{O}_{3}$ contents than primary clinopyroxene, either from spongy sectors (1.81-5.44 wt\%) or neoblasts in reaction zones (0.19-0.85 wt\%) (Fig. $4 \mathrm{a}$ and $\mathrm{b}$ ). Moreover, spongy clinopyroxene displays higher $\mathrm{CaO}$ and $\mathrm{TiO}_{2}$, and lower $\mathrm{Na}_{2} \mathrm{O}$ compared to both primary clinopyroxene and neoblasts from reaction zones. High $\mathrm{Cr}_{2} \mathrm{O}_{3}$ contents are shown by clinopyroxene neoblasts (Supplementary Table S1).

Primary aluminous spinel shows two well differentiated compositional ranges between the group -1 and -2 (Fig. $4 \mathrm{c}$ ). Spinel from the group-2 is characterized by a wide $\mathrm{Mg} \#$ range (69.9-81-8), low $\mathrm{Cr}_{2} \mathrm{O}_{3}$ (8.75-12.69 wt\%) and high $\mathrm{Al}_{2} \mathrm{O}_{3}$ (54.22-59.97 wt\%) contents, as in other Calatrava xenolith suites (Andía et al., 2018; Bianchini et al., 2010; Villaseca et al., 2010). Only one sample of the group-1 lherzolites contains spinel, which shows higher $\mathrm{Cr}_{2} \mathrm{O}_{3}$ (16.47-17.95 wt\%) and lower $\mathrm{Al}_{2} \mathrm{O}_{3}$ (49.74-52.56 wt\%) contents compared to those of group1 (Supplementary Table $\mathrm{S} 1$ ). Secondary spinel from reaction zones displays lower $\mathrm{Mg \#} \mathrm{(48.0-72.8)} \mathrm{and} \mathrm{Al}_{2} \mathrm{O}_{3}$ (43.31-53.92 wt\%), and higher $\mathrm{Cr}_{2} \mathrm{O}_{3}$ (12.01-20.03 wt\%) (Fig. 4c) $\mathrm{TiO}_{2}$ (0.18-3.04 wt\%) and $\mathrm{FeO}_{\text {tot }}$ (12.36-28.69 wt\%) contents compared to primary spinel (Supplementary Table S1). In the olivine-spinel mantle array (OSMA) plot (Fig. 5) 

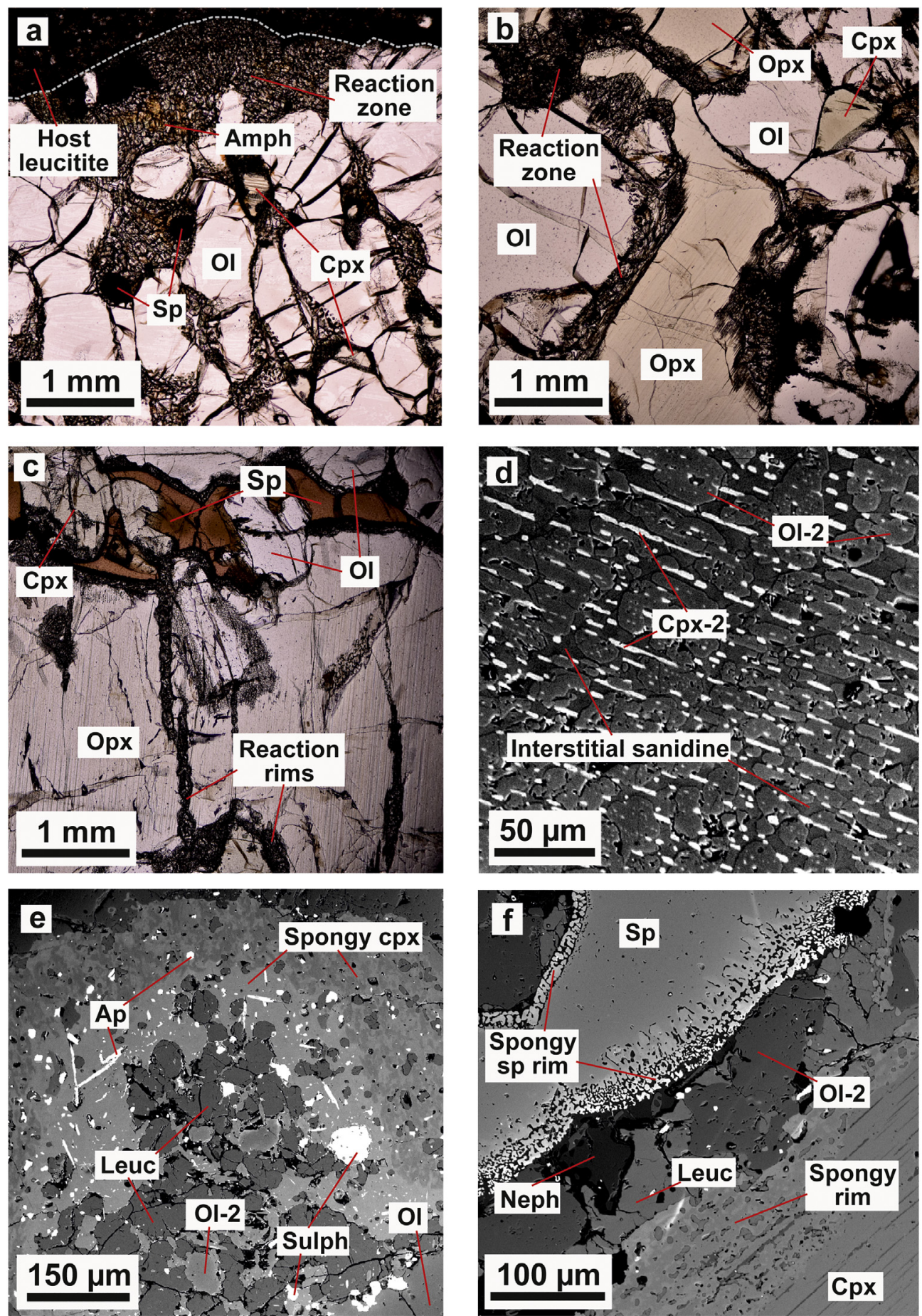

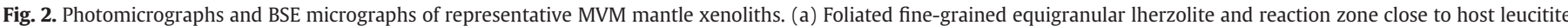

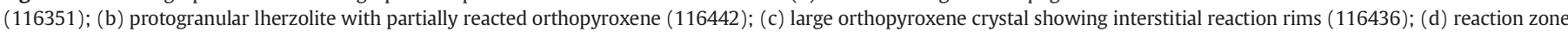

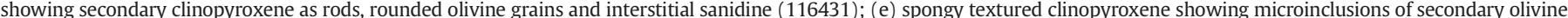

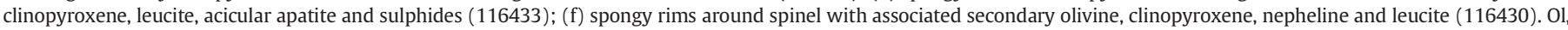

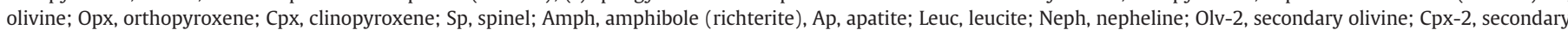
clinopyroxene.

the averaged composition of both coexisting minerals in a group-1 sample plot farther from fertile mantle compositions (Arai, 1992) than samples of group-2 MVM lherzolites.

Other secondary minerals that appear in reaction zones are $\mathrm{K}_{2} \mathrm{O}$ rich minerals, especially leucite (17.95-19.48 wt\%) and sanidine (7.92-10.63 wt\%), but some K-rich nepheline (4.23-4.43 wt\%) and richterite amphibole (1.22-1.96 wt\%) may also appear. These minerals clearly originated during the interaction with the K-rich host melt (Supplementary Table S1).

4.2.1.1. Geothermobarometry. Heat flow measurement studies in the central region of the Iberian Peninsula (Fernández et al., 1998) constrained the lithospheric thickness at around $110 \mathrm{~km}$, being approximately constant over a large area, while the depth to the Moho is 

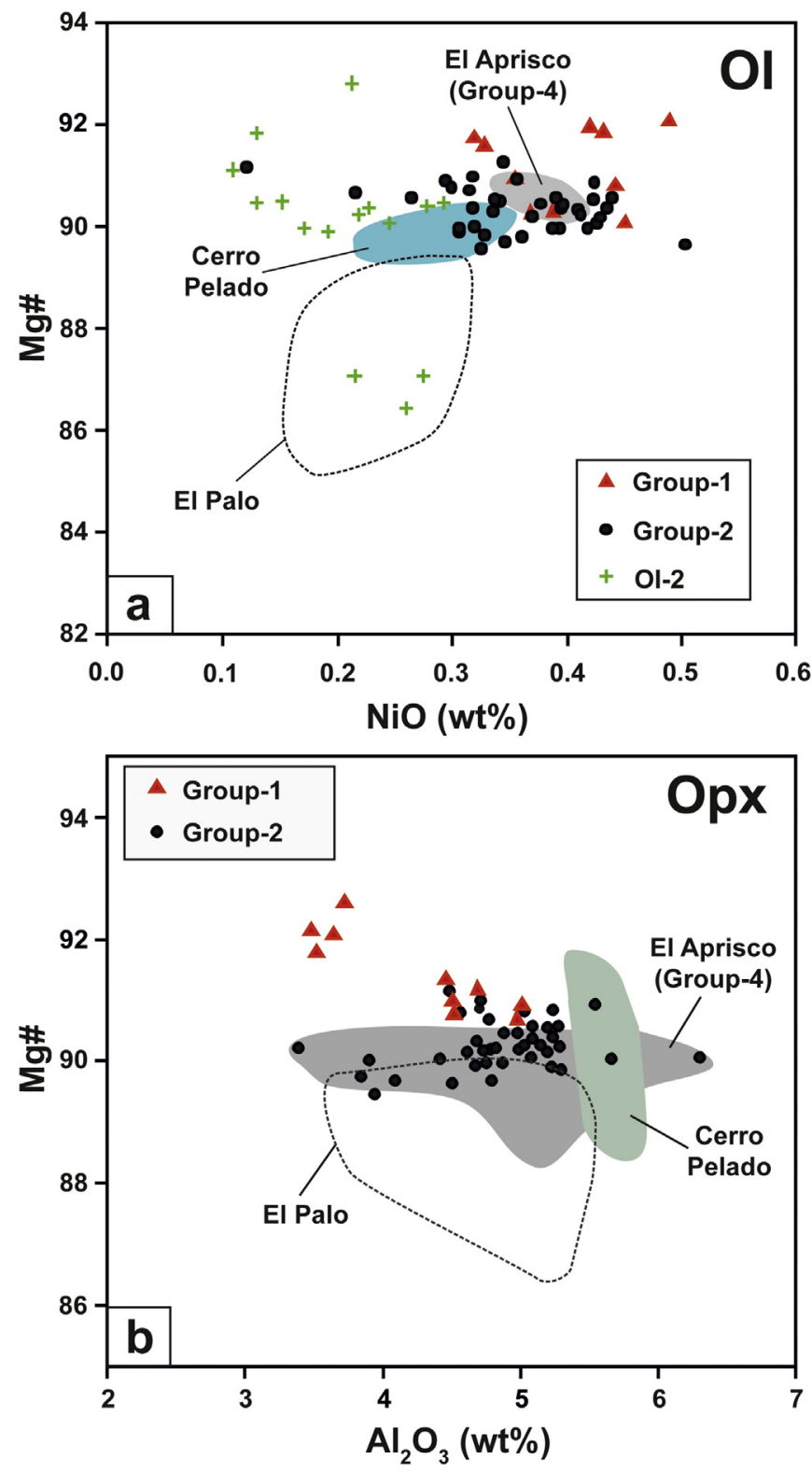

Fig. 3. Major element composition of olivine and orthopyroxene from the MVM lherzolites. The mineral compositional ranges of lherzolite xenoliths from other CVF volcanic centres are included for comparison (Bianchini et al., 2010; González-Jimenez et al., 2014; Villaseca et al., 2010). (a) $\mathrm{NiO}$ vs. $\mathrm{Mg \#}$ in olivine. (b) $\mathrm{Al}_{2} \mathrm{O}_{3}$ vs. $\mathrm{Mg \#}$ in orthopyroxene. Ol-2, secondary olivine. $\mathrm{Mg} \#=[\mathrm{Mg} /(\mathrm{Mg}+\mathrm{Fe} 2+)] \times 100$, in mol.

around $32 \pm 2 \mathrm{~km}$. The depth of MVM xenolith extraction is constrained to less than $70 \mathrm{~km}(<20 \mathrm{kbar})$ by the absence of garnet in sampled peridotites. Although for spinel lherzolites there are no precise geobarometers (e.g., Ackerman et al., 2007; Pearson et al., 2005), we have used the estimations of Nimis and Ulmer (1998) for clinopyroxene in order to approximate the depth of extraction of the MVM xenolith suite (Table 2). Estimated pressure in the MVM xenoliths ranges from 9.1 to $13.6 \mathrm{kbar}$, which is similar to that previously obtained in other CVF xenoliths (Andía et al., 2018; Villaseca et al., 2010). This result suggests that the MVM xenoliths were entrained at shallow lithospheric mantle levels, close to Moho depths. Pressure estimates from secondary
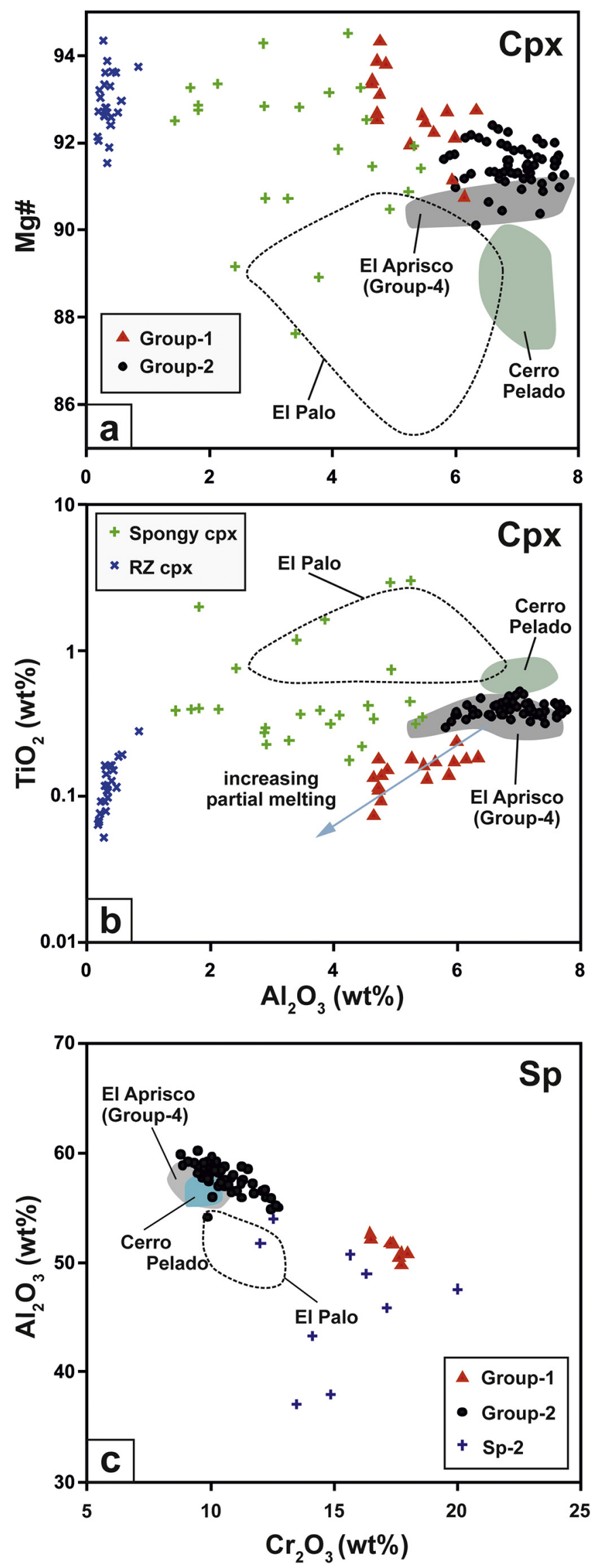


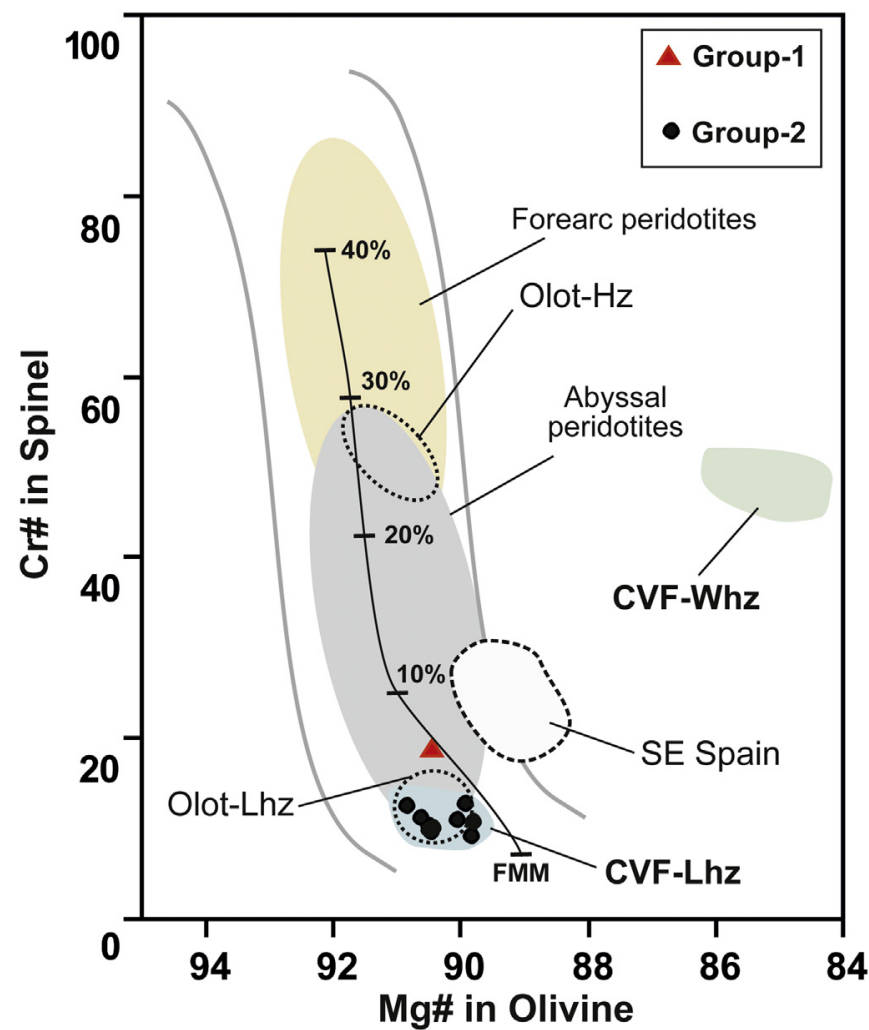

Fig. 5. Mineral chemistry of the MVM lherzolites in the Olivine-Spinel Mantle Array (OSMA) plot (Arai, 1994). The fields of peridotites from various tectonic settings and from other Iberian mantle xenoliths are also plotted (see Fig. 1A): Olot volcanic field (Bianchini et al., 2007; Galán et al., 2008); SE volcanic field (mainly from Tallante) (Beccaluva et al., 2004). Fertile MORB mantle (FMM) and partial melting trends are from Arai (1992). Forearc and abyssal peridotites compositional fields from Pearce et al. (2000). CVF-Whz and CVF-Lhz are wehrlite and lherzolite fields from some Calatrava volcanoes (Villaseca et al., 2010). Lhz, lherzolites; Hz, harzburgites Whz, wehrlites. $\mathrm{Cr} \#=[\mathrm{Cr} /(\mathrm{Cr}+\mathrm{Al}] \times 100$, in mol.

clinopyroxene (both spongy types and neoblasts) yield markedly lower pressures (2.9-4.5 kbar and 1.3-3.4 kbar, respectively; Table 2 and Fig. 6), indicating that xenoliths recrystallised after magma entrapment during the transport toward the surface. The lowest pressure estimates are recorded by secondary neoblasts in reaction zones with host magma. The lack of spinel replacement by plagioclase in mantle xenoliths is explained by the rapid xenolith transport along the volcanic conduit (O'Reilly and Griffin, 2010).

Three different calibrations of two-pyroxene thermometry (Brey and Köhler, 1990; Wells, 1977; Wood and Banno, 1973) were considered to estimate the temperatures of mantle equilibration of primary minerals in the MVM lherzolite xenoliths (Table 2). In general, these temperature estimates yield similar results, although the Brey and Köhler (1990) calibration gives lower temperatures (especially in secondary clinopyroxenes). The temperatures range from 618 to $942{ }^{\circ} \mathrm{C}$ (at pressures previously estimated), which are values that plot aligned along the geotherm of the south Tajo basin (central Spain) in Fig. 6 (Jiménez-Díaz et al., 2012). The obtained temperature estimates on

Fig. 4. Major element composition of clinopyroxene and spinel from the MVM lherzolites. The mineral compositional ranges of lherzolite xenoliths from other CVF volcanic centres are included for comparison (Bianchini et al., 2010; González-Jimenez et al., 2014; Villaseca et al., 2010). (a) $\mathrm{Al}_{2} \mathrm{O}_{3}$ vs. Mg\# in clinopyroxene. (b) $\mathrm{Al}_{2} \mathrm{O}_{3} \mathrm{Vs} \mathrm{TiO}_{2}$ in clinopyroxene; the group-1 clinopyroxene defines a trend (blue arrow) of increasing partial melting according to Uysal et al. (2007). (c) $\mathrm{Cr}_{2} \mathrm{O}_{3}$ vs. $\mathrm{Al}_{2} \mathrm{O}_{3}$ in spinel.RZ cpx, reaction zone. $\mathrm{Mg} \#=\left[\mathrm{Mg} /\left(\mathrm{Mg}+\mathrm{Fe}^{2+}\right)\right] \times 100$, in mol.
Table 2

Geothermobarometer $(P-T)$ estimates on the Morrón de Villamayor peridotite xenoliths.

\begin{tabular}{|c|c|c|c|c|}
\hline \multirow[t]{2}{*}{ Sample } & \multicolumn{3}{|l|}{$\mathrm{T}\left({ }^{\circ} \mathrm{C}\right)$} & \multirow{2}{*}{$\frac{\mathrm{P}(\mathrm{kbar})}{\mathrm{NU}}$} \\
\hline & BK & WB & W & \\
\hline \multicolumn{5}{|l|}{ Group 1} \\
\hline 116352 & 713 & 801 & 710 & 9.1 \\
\hline 116442 & 642 & 778 & 638 & 9.3 \\
\hline \multicolumn{5}{|l|}{ Group 2} \\
\hline 116351 & 618 & 862 & 737 & 10.2 \\
\hline 116428 & 908 & 958 & 840 & 12.5 \\
\hline 116430 & - & - & - & - \\
\hline 116431 & 839 & 878 & 757 & 13.7 \\
\hline 116433 & - & - & - & - \\
\hline 116434 & 740 & 740 & 607 & 11.1 \\
\hline 116435 & 942 & 917 & 801 & 13.6 \\
\hline 116436 & 941 & 815 & 685 & 11.3 \\
\hline 117174 & 749 & 762 & 634 & 9.5 \\
\hline 117183 & 858 & 902 & 774 & 13.1 \\
\hline \multicolumn{5}{|l|}{ Secondary cpx } \\
\hline 116351 (spongy) & 627 & 1182 & 1113 & 4.5 \\
\hline 116442 (spongy) & 887 & 1162 & 1089 & 3.2 \\
\hline 117183 (spongy) & 796 & - & - & 2.6 \\
\hline 117183 (spongy) & 786 & - & - & 3.3 \\
\hline 117183 (spongy) & 799 & 1170 & 1096 & 2.9 \\
\hline 117174 (spongy) & 876 & 1166 & 1085 & 4.5 \\
\hline $116431(\mathrm{RZ})$ & 1081 & - & - & 2.5 \\
\hline 116431 (RZ) & 1043 & - & - & 1.3 \\
\hline $116431(\mathrm{RZ})$ & 1083 & - & - & 3.9 \\
\hline $117174(\mathrm{RZ})$ & 1063 & - & - & 3.4 \\
\hline $117174(\mathrm{RZ})$ & 1092 & - & - & 3.4 \\
\hline
\end{tabular}

Abbreviations: BK, Brey and Köhler (1990); WB, Wood and Banno (1973); W, Wells (1977); UN, Nimis and Ulmer (1998). RZ: reaction zone.

MVM lherzolites are significantly lower compared to those estimates from other CVF xenolith suites (Villaseca et al., 2010; Andía et al., 2018; Fig. 6), except for samples of the El Aprisco group-4 lherzolites, which also plot close to this geotherm (Fig. 6). The low temperature of the MVM xenoliths could be because this volcanic centre is about 3 Ma older than the main Calatrava magmatic event. Moreover, temperature estimates on clinopyroxene neoblasts show a wide temperature

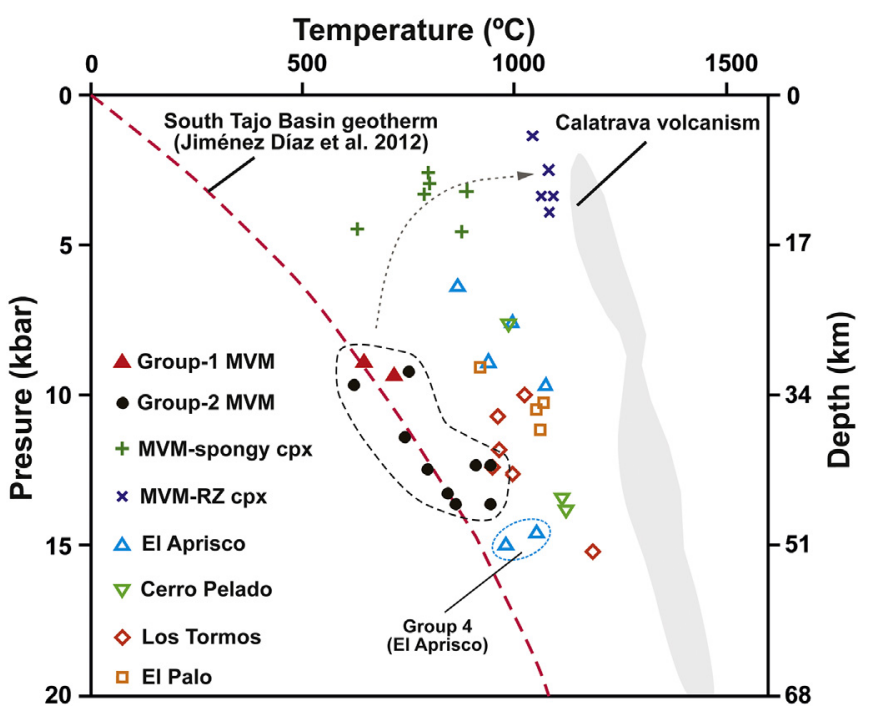

Fig. 6. Pressure vs. temperature diagram showing the estimated values obtained in the MVM lherzolites using the geobarometer of Nimis and Ulmer (1998) and the twopyroxene geothermometer of Brey and Köhler (1990). P-T estimations on lherzolite xenoliths from other CVF volcanic centres are also included for comparison (Andía, 2017; Andía et al., 2018; Bianchini et al., 2010; Villaseca et al., 2010). South Tajo basin geotherm (red line) from Jiménez-Díaz et al. (2012). P-T path of the Calatrava volcanism from Villaseca et al., 2019b. 
range (627-1092 $\left.{ }^{\circ} \mathrm{C}\right)$, converging their lower temperature values with those of primary clinopyroxene. The xenolith reaction with high- $T$ host melts (1250-1300 ${ }^{\circ} \mathrm{C}$ are experimental liquidus temperatures for silica-undersaturated alkaline magmas; Perinelli et al., 2008) may explain the high temperature values obtained in these MVM secondary clinopyroxenes. Accordingly, estimated P-T crystallization conditions of clinopyroxene-2 transits from the MVM subcontinental lithospheric mantle (MVM primary paragenesis) toward the $P-T$ path of the CVF alkaline magmatism (Villaseca et al., 2019b) (Fig. 6), indicating their variable neoformation conditions during volcanic transport.

\subsubsection{Trace element mineral composition}

Trace element analyses of rock-forming minerals from the two lherzolites groups are reported in Tables 3 and 4. Chondrite-normalized REE diagrams for the two clinopyroxene groups from MVM lherzolites (Fig. 7a and b) show common flat MREE and HREE (Sm-Lu) trends (between 3 and $10 \mathrm{x}$ chondrite values) and two different LREE patterns, with higher degree of LREE depletion (MORB type) for the group-2, suggesting cryptic metasomatism, as explained below. In the primordial mantle (PM)-normalized multitrace diagrams (Fig. 7c and d), clinopyroxenes from both lherzolite groups become positively fractionated toward almost flat at moderate incompatible elements, except for small Ti-(Zr)-P negative anomalies. Clinopyroxenes from the group-1 shows slight Sr-LREE-HFSE (Th, U, Nb, Ta, Pb) enrichments and low HREE and Ti contents compared to those of the group-2. These patterns are similar to those of clinopyroxene from depleted mantle, in contrast with the more abundant LREE-rich xenolith suites from the CVF, except for the El Aprisco group-4 lherzolites, which shows similar composition to the MVM lherzolites (Fig. 7a and c) (González-Jimenez et al., 2014;
Villaseca et al., 2010). In Fig. 7c, the group-4 clinopyroxenes from the El Aprisco lherzolites display similar $\mathrm{Nb}-\mathrm{Ta}$ and $\mathrm{Zr}$ negative anomalies to those defined by the MVM group-2 lherzolites. Nevertheless, primary clinopyroxenes of the MVM lherzolites show more LREE-Th-U-Nb-Ta depleted patterns than those from the Fe-Ti-rich xenolith suites of the CVF (Fig. 7b and d) (Bianchini et al., 2010; Villaseca et al., 2010).

Spongy clinopyroxene displays higher trace-element contents than primary types (Table 3) (Fig. 7), showing extremely enriched LREE, LILE (Rb, Ba, Th, U, Sr, Pb) and HFSE (Nb, Ta, Zr, Hf) contents, along with prominent Th-U and $\mathrm{K}$ spikes in PM-normalized diagrams, approaching a trace element pattern similar to the host leucitite rocks. Moreover, spongy clinopyroxene has similar composition irrespective of their lherzolite group.

Trace element compositions of orthopyroxene, olivine and spinel do not mimic the patterns of coexisting clinopyroxene in chondrite and PM-normalized trace element diagrams. Orthopyroxene from MVM lherzolites presents positively fractionated REE patterns with HREE approaching chondrite values and LREE down to $0.01 \mathrm{x}$ chondrite. MVM orthopyroxenes show the same LREE depletion than orthopyroxenes from other studied CVF xenoliths (Bianchini et al., 2010; Villaseca et al., 2010) (Supplementary Fig. S2). Multitrace normalized diagrams of olivine, orthopyroxene and spinel (Supplementary Fig. S2) show the same $\mathrm{Pb}-\mathrm{P}$ positive and $\mathrm{Ce}-\mathrm{Sr}-\mathrm{Nd}$ negative anomalies.

\subsection{Whole-rock composition}

\subsubsection{Major and trace elements}

Whole-rock major and trace element composition of six MVM mantle xenoliths and two host leucitite samples are reported in Table 5. In

Table 3

Average trace element composition ( $\mathrm{ppm}$ ) of clinopyroxenes from the Morrón de Villamayor peridotite xenoliths.

\begin{tabular}{|c|c|c|c|c|c|c|c|c|c|c|c|c|c|c|}
\hline \multirow[t]{2}{*}{ Sample } & \multicolumn{2}{|l|}{ Group 1} & \multicolumn{6}{|l|}{ Group 2} & \multicolumn{6}{|c|}{ Clinopyroxene-spongy } \\
\hline & 116352 & 116442 & 116351 & 116428 & 116430 & 116435 & 116436 & 117183 & 116352 & 116442 & 116351 & 116428 & 116430 & 117183 \\
\hline No. spots & 4 & 9 & 3 & 8 & 10 & 4 & 7 & 5 & 3 & 3 & 4 & 4 & 4 & 5 \\
\hline $\mathrm{P}$ & 3.30 & 2.53 & 530 & 15.8 & 72.1 & 10.38 & 6.86 & 12.5 & 262 & 123 & 563 & 1305 & 430 & 713 \\
\hline K & 95.5 & 32.2 & 88.6 & 2.63 & 65.6 & 2.58 & 0.307 & 1.22 & 8067 & 7113 & 10450 & 9675 & 13733 & 9160 \\
\hline $\mathrm{Sc}$ & 56.3 & 68.6 & 74.4 & 56.7 & 70.5 & 63.6 & 31.9 & 66.0 & 68.1 & 62.9 & 85.0 & 56.6 & 62.0 & 68.9 \\
\hline $\mathrm{Ti}$ & 1029 & 635 & 2365 & 2413 & 2366 & 2153 & 1238 & 1980 & 3520 & 2763 & 3928 & 7085 & 5658 & 4096 \\
\hline V & 205 & 205 & 297 & 245 & 252 & 221 & 137 & 222 & 211 & 137 & 227 & 155 & 140 & 170 \\
\hline $\mathrm{Cr}$ & 5430 & 11,423 & 6657 & 7313 & 5743 & 5190 & 3693 & 7158 & 8400 & 11,283 & 7798 & 5193 & 4506 & 6828 \\
\hline Mn & 537 & 879 & 610 & 750 & 704 & 692 & 464 & 523 & 528 & 496 & 468 & 503 & 477 & 390 \\
\hline Co & 15.5 & 18.3 & 21.4 & 23.0 & 22.8 & 18.5 & 13.6 & 17.5 & 20.1 & 23.0 & 20.0 & 21.5 & 21.7 & 17.3 \\
\hline $\mathrm{Ni}$ & 219 & 269 & 305 & 351 & 303 & 261 & 199 & 263 & 231 & 243 & 231 & 123 & 195 & 199 \\
\hline $\mathrm{Rb}$ & 0.024 & 0.001 & 0.037 & 0.021 & 0.002 & 0.026 & 0.004 & 0.002 & 121 & 71.8 & 120 & 112 & 138 & 86.4 \\
\hline $\mathrm{Sr}$ & 18.0 & 66.5 & 5.19 & 11.2 & 9.67 & 10.5 & 3.29 & 14.8 & 279 & 260 & 268 & 514 & 308 & 251 \\
\hline Y & 8.80 & 8.29 & 19.4 & 16.5 & 23.2 & 22.5 & 11.4 & 14.9 & 12.2 & 8.38 & 13.3 & 15.2 & 11.6 & 12.7 \\
\hline $\mathrm{Zr}$ & 4.16 & 8.72 & 8.55 & 8.49 & 10.88 & 12.9 & 6.13 & 11.7 & 56.7 & 70.9 & 65.3 & 194 & 100 & 84.8 \\
\hline $\mathrm{Nb}$ & 0.053 & 0.283 & 0.002 & 0.018 & 0.002 & 0.004 & 0.004 & 0.009 & 7.70 & 11.0 & 9.78 & 7.38 & 12.7 & 7.46 \\
\hline $\mathrm{Ba}$ & 0.021 & 0.093 & 0.001 & 0.511 & 0.073 & 0.002 & 0.001 & 0.051 & 126 & 134 & 55.0 & 55.8 & 95.5 & 64.9 \\
\hline La & 0.29 & 0.64 & 0.01 & 0.04 & 0.04 & 0.02 & 0.01 & 0.05 & 9.57 & 8.33 & 13.58 & 26.45 & 11.46 & 13.16 \\
\hline $\mathrm{Ce}$ & 1.03 & 2.20 & 0.29 & 0.56 & 0.52 & 0.45 & 0.24 & 0.68 & 26.03 & 24.23 & 34.18 & 71.75 & 32.95 & 31.94 \\
\hline $\operatorname{Pr}$ & 0.18 & 0.45 & 0.15 & 0.23 & 0.22 & 0.20 & 0.12 & 0.26 & 4.15 & 3.64 & 4.52 & 10.20 & 5.10 & 4.71 \\
\hline $\mathrm{Nd}$ & 1.11 & 2.84 & 1.66 & 2.15 & 2.06 & 1.80 & 1.02 & 2.05 & 18.23 & 18.23 & 21.31 & 43.70 & 24.20 & 21.28 \\
\hline $\mathrm{Sm}$ & 0.49 & 1.03 & 1.19 & 1.19 & 1.26 & 1.12 & 0.68 & 1.10 & 3.86 & 3.87 & 4.37 & 9.65 & 5.58 & 4.43 \\
\hline $\mathrm{Eu}$ & 0.23 & 0.37 & 0.51 & 0.57 & 0.57 & 0.51 & 0.30 & 0.52 & 1.01 & 1.00 & 1.02 & 2.29 & 1.26 & 1.09 \\
\hline Gd & 0.93 & 1.32 & 2.11 & 2.11 & 2.58 & 2.12 & 1.16 & 1.89 & 2.59 & 2.76 & 3.07 & 5.58 & 3.36 & 3.45 \\
\hline $\mathrm{Tb}$ & 0.19 & 0.22 & 0.41 & 0.43 & 0.48 & 0.49 & 0.25 & 0.38 & 0.35 & 0.34 & 0.39 & 0.75 & 0.40 & 0.43 \\
\hline Dy & 1.40 & 1.49 & 3.28 & 2.86 & 3.66 & 3.32 & 1.76 & 2.63 & 2.10 & 1.60 & 2.44 & 3.48 & 2.06 & 2.35 \\
\hline Ho & 0.35 & 0.30 & 0.72 & 0.68 & 0.85 & 0.79 & 0.41 & 0.54 & 0.45 & 0.26 & 0.46 & 0.57 & 0.42 & 0.40 \\
\hline $\mathrm{Er}$ & 1.10 & 0.88 & 2.16 & 1.96 & 2.62 & 2.89 & 1.22 & 1.71 & 1.22 & 0.70 & 1.18 & 1.58 & 1.18 & 1.19 \\
\hline $\mathrm{Tm}$ & 0.15 & 0.13 & 0.32 & 0.29 & 0.38 & 0.33 & 0.18 & 0.25 & 0.16 & 0.10 & 0.17 & 0.17 & 0.16 & 0.16 \\
\hline $\mathrm{Yb}$ & 1.03 & 0.68 & 2.13 & 1.73 & 2.30 & 2.07 & 1.03 & 1.53 & 1.01 & 0.52 & 1.04 & 1.15 & 1.09 & 0.98 \\
\hline $\mathrm{Lu}$ & 0.13 & 0.11 & 0.28 & 0.24 & 0.32 & 0.35 & 0.14 & 0.25 & 0.13 & 0.07 & 0.14 & 0.15 & 0.13 & 0.16 \\
\hline $\mathrm{Hf}$ & 0.12 & 0.26 & 0.47 & 0.53 & 0.67 & 0.67 & 0.32 & 0.55 & 1.07 & 1.23 & 1.26 & 5.46 & 2.26 & 2.08 \\
\hline Та & 0.003 & 0.017 & 0.001 & 0.001 & 0.001 & 0.001 & 0.001 & 0.001 & 0.446 & 0.617 & 0.495 & 0.603 & 0.856 & 0.422 \\
\hline $\mathrm{Pb}$ & 0.006 & 0.165 & 0.011 & 0.097 & 0.059 & 0.013 & 0.007 & 0.023 & 2.24 & 2.37 & 17.8 & 5.18 & 5.05 & 4.32 \\
\hline Th & 0.003 & 0.028 & 0.001 & 0.010 & 0.003 & 0.002 & 0.002 & 0.006 & 4.13 & 6.10 & 7.28 & 9.18 & 11.1 & 5.81 \\
\hline $\mathrm{U}$ & 0.001 & 0.005 & 0.001 & 0.002 & 0.004 & 0.001 & 0.001 & 0.013 & 1.09 & 1.32 & 1.32 & 1.03 & 2.57 & 1.06 \\
\hline
\end{tabular}


Table 4

Average trace element composition (ppm) of orthopyroxene, olivine and spinel from the Morrón de Villamayor peridotite xenoliths.

\begin{tabular}{|c|c|c|c|c|c|c|c|c|c|c|c|c|c|c|}
\hline \multirow[t]{3}{*}{ Sample } & \multicolumn{5}{|c|}{ Orthopyroxene } & \multicolumn{5}{|l|}{ Olivine } & \multicolumn{4}{|l|}{ Spinel } \\
\hline & \multicolumn{2}{|l|}{ Group 1} & \multicolumn{3}{|l|}{ Group 2} & \multicolumn{2}{|l|}{ Group 1} & \multicolumn{3}{|l|}{ Group 2} & \multirow{2}{*}{$\frac{\text { Group } 1}{116352}$} & \multicolumn{3}{|l|}{ Group 2} \\
\hline & 116352 & 116442 & 116435 & 116436 & 117183 & 116352 & 116442 & 116435 & 116436 & 117183 & & 116435 & 116436 & 117183 \\
\hline No. spots & 7 & 7 & 6 & 6 & 6 & 7 & 7 & 7 & 7 & 6 & 5 & 6 & 6 & 5 \\
\hline $\mathrm{P}$ & 2.75 & 4.76 & 12.3 & 16.9 & 21.8 & 1.01 & 1.30 & 8.57 & 6.86 & 1.08 & 100 & 183 & 105 & 386 \\
\hline K & 0.61 & 3.11 & 28.5 & 2.72 & 41.9 & 4.24 & 17.8 & 1.02 & 3.93 & 6.43 & 4.20 & 28.7 & 36.8 & 4.20 \\
\hline $\mathrm{Ca}$ & 9071 & 6279 & 5135 & 5622 & 6262 & 8.57 & 57.9 & 98.7 & 161.9 & 19.3 & 4.60 & 15.1 & 7.57 & 24.9 \\
\hline $\mathrm{Sc}$ & 22.7 & 18.9 & 22.2 & 20.1 & 19.1 & 2.28 & 2.61 & 2.97 & 2.69 & 2.04 & 28.8 & 30.8 & 18.3 & 145 \\
\hline $\mathrm{Ti}$ & 463 & 261 & 736 & 738 & 619 & 7.13 & 6.14 & 13.6 & 13.6 & 24.9 & 1.55 & 3.65 & 1.36 & 0.530 \\
\hline V & 116 & 83 & 110 & 106 & 94.9 & 1.75 & 2.15 & 5.48 & 2.72 & 1.20 & 550 & 712 & 644 & 191 \\
\hline $\mathrm{Cr}$ & 4730 & 5430 & 2550 & 2814 & 3327 & 22.7 & 37.5 & 65.0 & 66.6 & 7.26 & 496 & 414 & 379 & 395 \\
\hline Mn & 1008 & 913 & 1154 & 1140 & 1083 & 979 & 801 & 1060 & 1026 & 949 & 1315 & 1225 & 1203 & 812 \\
\hline Co & 50 & 46 & 48 & 49 & 49 & 134 & 117 & 138 & 135 & 125 & 226 & 248 & 342 & 364 \\
\hline $\mathrm{Ni}$ & 640 & 570 & 560 & 589 & 605 & 2779 & 2563 & 2730 & 2627 & 2708 & 1626 & 2387 & 2577 & 1613 \\
\hline $\mathrm{Rb}$ & 0.014 & 0.011 & 0.152 & 0.030 & 0.231 & 0.019 & 0.010 & 0.012 & 0.007 & 0.006 & 0.035 & 0.058 & 0.060 & 0.015 \\
\hline $\mathrm{Sr}$ & 0.216 & 0.595 & 0.091 & 0.046 & 0.436 & 0.015 & 0.009 & 0.024 & 0.031 & 0.001 & 0.034 & 0.095 & 0.045 & 0.070 \\
\hline Y & 1.05 & 0.427 & 1.05 & 1.15 & 1.12 & 0.004 & 0.027 & 0.032 & 0.012 & 0.010 & 0.001 & 0.014 & 0.043 & 0.001 \\
\hline $\mathrm{Zr}$ & 0.624 & 0.438 & 0.702 & 0.668 & 0.647 & 0.032 & 0.012 & 0.035 & 0.019 & 0.006 & 0.106 & 0.137 & 0.101 & 0.120 \\
\hline $\mathrm{Nb}$ & 0.003 & 0.005 & 0.008 & 0.007 & 0.027 & 0.001 & 0.020 & 0.004 & 0.004 & 0.012 & 0.037 & 0.035 & 0.025 & 0.012 \\
\hline $\mathrm{Ba}$ & 0.019 & 0.006 & 0.511 & 0.019 & 0.303 & 0.003 & 0.005 & 0.034 & 0.004 & 0.012 & 0.002 & 0.249 & 0.029 & 0.049 \\
\hline La & 0.004 & 0.007 & 0.004 & 0.004 & 0.006 & 0.001 & 0.001 & 0.003 & 0.002 & 0.003 & 0.008 & 0.011 & 0.006 & 0.006 \\
\hline $\mathrm{Ce}$ & 0.012 & 0.019 & 0.007 & 0.003 & 0.008 & 0.002 & 0.002 & 0.002 & 0.001 & 0.002 & 0.002 & 0.001 & 0.001 & 0.004 \\
\hline $\operatorname{Pr}$ & 0.005 & 0.005 & 0.003 & 0.002 & 0.005 & 0.002 & 0.002 & 0.002 & 0.002 & 0.002 & 0.002 & 0.003 & 0.005 & 0.002 \\
\hline Nd & 0.013 & 0.041 & 0.014 & 0.017 & 0.028 & 0.001 & 0.011 & 0.003 & 0.001 & 0.002 & 0.010 & 0.005 & 0.004 & 0.001 \\
\hline $\mathrm{Sm}$ & 0.018 & 0.022 & 0.015 & 0.017 & 0.007 & 0.003 & 0.007 & 0.005 & 0.001 & 0.002 & 0.010 & 0.006 & 0.020 & 0.001 \\
\hline $\mathrm{Eu}$ & 0.015 & 0.013 & 0.011 & 0.009 & 0.012 & 0.003 & 0.005 & 0.004 & 0.002 & 0.005 & 0.014 & 0.009 & 0.010 & 0.010 \\
\hline Gd & 0.046 & 0.018 & 0.040 & 0.048 & 0.060 & 0.003 & 0.002 & 0.001 & 0.010 & 0.013 & 0.019 & 0.011 & 0.023 & 0.008 \\
\hline $\mathrm{Tb}$ & 0.013 & 0.007 & 0.011 & 0.015 & 0.012 & $<0.001$ & $<0.001$ & $<0.001$ & $<0.001$ & $<0.001$ & 0.001 & 0.001 & 0.001 & 0.001 \\
\hline Dy & 0.147 & 0.058 & 0.116 & 0.123 & 0.120 & 0.001 & 0.006 & 0.003 & 0.001 & 0.001 & 0.007 & 0.004 & 0.005 & 0.013 \\
\hline Ho & 0.036 & 0.017 & 0.034 & 0.037 & 0.045 & 0.001 & 0.001 & 0.002 & 0.002 & $<0.001$ & 0.004 & 0.005 & 0.005 & 0.001 \\
\hline $\mathrm{Er}$ & 0.130 & 0.069 & 0.139 & 0.160 & 0.165 & 0.004 & 0.006 & 0.003 & 0.005 & 0.002 & 0.001 & 0.001 & 0.001 & 0.006 \\
\hline $\operatorname{Tm}$ & 0.028 & 0.009 & 0.028 & 0.037 & 0.030 & $<0.001$ & 0.001 & 0.002 & $<0.001$ & 0.001 & 0.001 & 0.001 & 0.002 & 0.001 \\
\hline $\mathrm{Yb}$ & 0.227 & 0.114 & 0.307 & 0.288 & 0.247 & 0.009 & 0.010 & 0.022 & 0.016 & 0.010 & 0.018 & 0.032 & 0.024 & 0.009 \\
\hline Lu & 0.045 & 0.019 & 0.065 & 0.056 & 0.038 & 0.003 & 0.002 & 0.005 & 0.005 & 0.005 & 0.007 & 0.008 & 0.004 & 0.003 \\
\hline $\mathrm{Hf}$ & 0.029 & 0.017 & 0.037 & 0.041 & 0.028 & 0.003 & 0.002 & 0.002 & 0.002 & $<0.001$ & 0.012 & 0.011 & 0.013 & 0.002 \\
\hline Та & 0.002 & 0.001 & 0.001 & $<0.001$ & 0.000 & $<0.001$ & $<0.001$ & $<0.001$ & $<0.001$ & $<0.001$ & 0.001 & 0.001 & 0.001 & $<0.001$ \\
\hline $\mathrm{Pb}$ & 0.012 & 0.035 & 0.014 & 0.006 & 0.053 & 0.002 & 0.019 & 0.086 & $<0.001$ & 0.008 & 0.046 & 0.149 & 0.080 & 0.115 \\
\hline Th & $<0.001$ & 0.001 & $<0.001$ & $<0.001$ & $<0.001$ & $<0.001$ & $<0.001$ & $<0.001$ & $<0.001$ & $<0.001$ & $<0.001$ & 0.001 & $<0.001$ & $<0.001$ \\
\hline $\mathrm{U}$ & $<0.001$ & 0.001 & $<0.001$ & $<0.001$ & $<0.001$ & $<0.001$ & $<0.001$ & 0.008 & $<0.001$ & $<0.001$ & $<0.001$ & $<0.001$ & $<0.001$ & 0.001 \\
\hline
\end{tabular}

Harker diagrams of MgO versus major and trace elements, the MVM lherzolites plot in the range of other CVF lherzolites, close to the primordial mantle composition or moderately depleted values. They also show a small chemical compositional variety (Fig. 8). The MVM lherzolites show negative correlation of $\mathrm{Al}_{2} \mathrm{O}_{3}, \mathrm{CaO}, \mathrm{FeO}$ and $\mathrm{TiO}_{2}$ with $\mathrm{MgO}$ contents, as other CVF xenolith trends (Fig. 8), a common feature in mantle xenolith suites (e.g., Ackerman et al., 2007; Bianchini et al., 2007; Downes, 2001). The MVM lherzolites do not have a Fe-Ti-rich trend as El Palo (Bianchini et al., 2010) and Cerro Pelado lherzolite to wehrlite samples (Villaseca et al., 2010) do, which also show low MgO values. Compared to the El Aprisco mantle xenolith groups, the MVM lherzolites have a more limited compositional range being similar to the El Aprisco group-4 (González-Jimenez et al., 2014) (Fig. 8). The only analysed MVM group-1 lherzolite (116352) contains less MgO than any other MVM group-2 lherzolite.

Whole-rock chondrite-normalized REE patterns are less varied than the previously studied Calatrava xenolith suites (Bianchini et al., 2010; Villaseca et al., 2010) (Fig. 9a). They have flat REE patterns and overall low trace element contents, with negative $\mathrm{Nb}-\mathrm{Ta}$ and marked positive $\mathrm{U}, \mathrm{K}$ and $\mathrm{Pb}$ anomalies. Moreover, bulk-rock patterns are not parallel with equivalent clinopyroxene patterns, showing a marked LREE-LILE-HFSE (Th-U-Pb) enrichment with respect to clinopyroxene compositions (Fig. 9). The only analysed sample from the group-1 lherzolite presents similar REE values than those in the group-2, although with slightly lower MREE and HREE contents (Fig. 9a). Two lherzolite samples (117184 and 116440 ) have chemical compositions that resemble the host leucitite magma, displaying the highest LILE (including K) and REE contents of the MVM peridotite suite. In Fig. 9 these lherzolites have chondrite-normalized REE patterns parallel to the host leucitite, suggesting a significant host-melt contamination.

\subsubsection{Sr-Nd isotopes}

$\mathrm{Sr}-\mathrm{Nd}$ isotope composition of five MVM peridotite xenoliths, one clinopyroxene separate and two host leucitites are reported in Table 6. The clinopyroxene separate from lherzolite 116429 represents an original pre-entrainment isotopic signature of the sampled lithospheric mantle beneath this volcano. Isotope data from most of the other MVM lherzolite xenoliths are variably mixed with the host leucitite melt, as discussed below. Thus, lherzolite whole-rock data define a trend toward the EMII lithospheric component, plotting close to the compositional field of host leucitites (Fig. 10). This isotopic composition strongly contrasts with the characteristic FOZO-HIMU isotopic signature exhibited by the bulk CVF volcanism and most of the studied CVF xenolith suites (Fig. 10). The MVM lherzolites have strontium isotope ratios similar in range to the host leucitite, which are higher compared to the rest of studied CVF xenoliths (Bianchini et al., 2010; Villaseca et al., 2010) (Fig. 10). Xenoliths from this K-rich volcanic centre also show a low radiogenic neodymium composition, defining a compositional field converging to their host leucitite, while xenoliths from the rest of the CVF display compositions more similar to their host Na-rich alkaline melts (Fig. 10). Nevertheless, the MVM clinopyroxene separate defines a singular lithospheric mantle in the CVF as displayed by its initial high $\mathrm{Sr}\left({ }^{87} \mathrm{Sr} /{ }^{86} \mathrm{Sr}=0.706104\right)$ and intermediate $\mathrm{Nd}\left({ }^{143} \mathrm{Nd} /{ }^{144} \mathrm{Nd}=\right.$ 

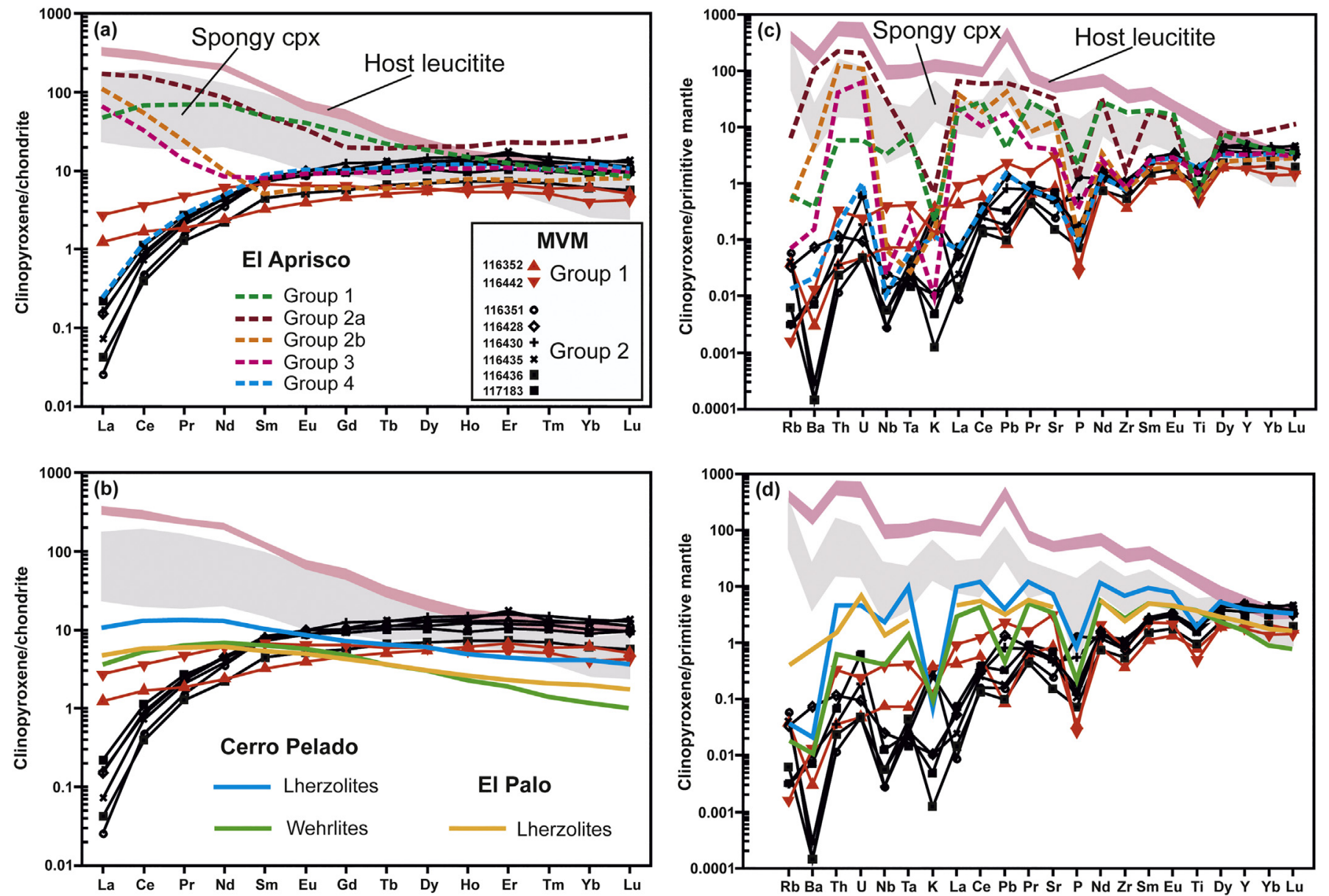

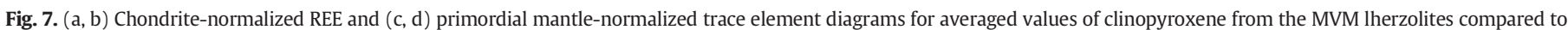

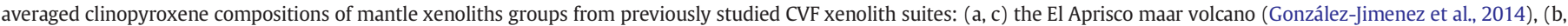

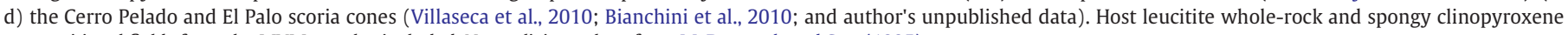
compositional fields from the MVM are also included. Normalizing values from McDonough and Sun (1995).

0.512830 ) radiogenic ratios (Table 6), not previously recorded in other xenolith suites of this volcanic field (Fig. 10).

\section{Discussion}

\subsection{Host magma-xenolith reaction and decompression during transport}

Studied reaction textures are the result of interaction between MVM mantle xenoliths and their host leucitite magma during or after entrainment. Clinopyroxene and spinel close to the xenolith rims in most MVM lherzolites present spongy texture (Fig. 2) similar to that described in many mantle xenoliths worldwide (e.g., Marchev et al., 2017; Matusiak-Małek et al., 2017; Pan et al., 2018; Shaw et al., 2006; Shaw and Dingwell, 2008; Su et al., 2011). The MVM spongy clinopyroxene is characterized by its lower $\mathrm{Al}_{2} \mathrm{O}_{3}, \mathrm{Na}_{2} \mathrm{O}$ and higher $\mathrm{MgO}, \mathrm{CaO}$ contents than coexisting primary crystals (Fig. $4 \mathrm{a}$ and b), indicating that these textures have a melt interaction origin (Pan et al., 2018; Shaw et al., 2006; Shaw and Dingwell, 2008). The equilibration temperature of secondary clinopyroxene is higher $\left(627-1092{ }^{\circ} \mathrm{C}\right.$ ) than primary types $\left(618-942^{\circ} \mathrm{C}\right.$ ) and closer to the $P$-T estimates for the Calatrava volcanism (Fig. 6). Moreover, pressure estimations of these secondary clinopyroxenes indicate their shallow formation conditions (1.3-4.5 kbar). In an $\mathrm{Al}^{\mathrm{IV}}$ vs. $\mathrm{Al}^{\mathrm{VI}}$ diagram (Fig. 11) it is clear that mineral chemical changes may be related to a decompression process, and therefore the formation of spongy clinopyroxene over primary clinopyroxene grains would be generated during volcanic transport. In addition, in PM- normalized trace element diagrams, spongy clinopyroxenes show similar patterns than the host leucitite (Fig. 7) suggesting a strong host melt interaction during its recrystallization (Su et al., 2011). The presence of leucite and apatite neoblasts (Fig. 2e) indicates a significant K- and Penrichment in spongy and reacted clinopyroxene domains, which has been induced by host leucitite melt infiltration during the xenolith entrainment and transport, since these elements are highly concentrated in the MVM leucitites (Fig. 9). Whole-rock analyses of both lherzolite groups in PM-normalized trace element diagrams show patterns with positive anomalies in LILE and LREE enrichment (Fig. 9) compared to clinopyroxene trace element compositions, which may be explained by the inclusion of reaction zones in the crushed sample.

Reaction zones on orthopyroxene crystals also increase toward the host leucitite contact (Fig. 2a). According to Shaw et al. (2006), orthopyroxene strongly reacts with compositionally contrasted infiltrating melts, especially with those of silica-undersaturated composition. The MVM lherzolite spinels display a $\mathrm{Cr} \#$ increase from unreacted core to secondary reaction rims (Figs. 4c and 11c) due to reaction with moderately siliceous melts from orthopyroxene dissolution (Fig. 2c) (Shaw and Dingwell, 2008). Moreover, Bonadiman et al. (2005) suggest that reaction textures generated by the influx of ultrapotassic melts into the lithospheric mantle may generate new potassic minerals, as those described as fine-grained neoblasts in the MVM lherzolites (leucite, sanidine, K-rich nepheline and richterite).

The xenolith ascent rate to surface has been assumed to be too rapidly to experience any residence at shallow levels (O'Reilly and Griffin, 
Table 5

Whole-rock major (wt\%) and trace element (ppm) analyses of the Morrón de Villamayor peridotite xenoliths and host leucitite.

\begin{tabular}{|c|c|c|c|c|c|c|c|c|}
\hline \multirow[t]{3}{*}{ Sample } & \multicolumn{6}{|c|}{ Lherzolitic xenoliths } & \multicolumn{2}{|c|}{ Host leucitite } \\
\hline & \multirow{2}{*}{$\frac{\text { Group } 1}{116352}$} & \multicolumn{5}{|l|}{ Group 2} & \multirow[b]{2}{*}{114409} & \multirow[b]{2}{*}{117189} \\
\hline & & 116435 & 116436 & 116440 & 117183 & 117184 & & \\
\hline $\mathrm{SiO}_{2}$ & 44.5 & 44.1 & 44.2 & 41.7 & 44.6 & 45.2 & 43.3 & 44.9 \\
\hline $\mathrm{TiO}_{2}$ & 0.056 & 0.089 & 0.078 & 0.098 & 0.068 & 0.225 & 1.84 & 2.30 \\
\hline $\mathrm{Al}_{2} \mathrm{O}_{3}$ & 2.54 & 2.91 & 2.57 & 2.77 & 2.54 & 3.84 & 8.29 & 10.16 \\
\hline $\mathrm{Fe}_{2} \mathrm{O}_{3}$ & 8.84 & 8.72 & 8.94 & 8.69 & 8.56 & 8.82 & 10.30 & 9.68 \\
\hline $\mathrm{MgO}$ & 39.2 & 39.5 & 40.9 & 40.8 & 40.3 & 32.3 & 18.45 & 11.85 \\
\hline $\mathrm{MnO}$ & 0.125 & 0.129 & 0.130 & 0.132 & 0.142 & 0.144 & 0.15 & 0.16 \\
\hline $\mathrm{NiO}$ & 0.274 & 0.269 & 0.269 & 0.258 & 0.234 & 0.218 & 0.08 & 0.03 \\
\hline $\mathrm{Cr}_{2} \mathrm{O}_{3}$ & 0.889 & 0.699 & 0.631 & 0.950 & 0.877 & 0.693 & 0.21 & 0.24 \\
\hline $\mathrm{CaO}$ & 2.47 & 3.23 & 2.66 & 3.33 & 3.09 & 4.03 & 10.06 & 12.17 \\
\hline $\mathrm{Na}_{2} \mathrm{O}$ & 0.230 & 0.390 & 0.280 & 0.590 & 0.260 & 0.800 & 2.27 & 2.34 \\
\hline $\mathrm{K}_{2} \mathrm{O}$ & 0.140 & 0.340 & 0.220 & 0.480 & 0.140 & 1.24 & 3.47 & 3.56 \\
\hline $\mathrm{P}_{2} \mathrm{O}_{5}$ & 0.006 & 0.007 & 0.005 & 0.008 & 0.009 & 0.100 & 0.93 & 1.09 \\
\hline Total & 98.1 & 99.4 & 99.9 & 98.6 & 100.2 & 99.0 & 100 & 100 \\
\hline Sc & 12.0 & 14.0 & 13.0 & 12.0 & 12.0 & 14.0 & 20.0 & 26.0 \\
\hline V & 63.0 & 68.0 & 64.0 & 67.0 & 58.0 & 78.0 & 173 & 222 \\
\hline $\mathrm{Cr}$ & 3040 & 2390 & 2160 & 3250 & 3000 & 2370 & 720 & 820 \\
\hline Co & 107 & 106 & 106 & 107 & 116 & 103 & 75.0 & 54.0 \\
\hline $\mathrm{Ni}$ & 2150 & 2110 & 2110 & 2030 & 1840 & 1710 & 640 & 200 \\
\hline $\mathrm{Cu}$ & 30.0 & 40.0 & 40.0 & 60.0 & 40.0 & 40.0 & 60.0 & 70.0 \\
\hline $\mathrm{Zn}$ & 50.0 & 50.0 & 40.0 & 60.0 & 80.0 & 40.0 & 90.0 & 100 \\
\hline $\mathrm{Ga}$ & 3.00 & 3.00 & 2.00 & 3.00 & 2.00 & 2.00 & 14.0 & 19.0 \\
\hline Ge & $<0.9$ & $<0.9$ & $<0.9$ & $<0.9$ & 0.80 & 0.90 & 1.40 & 1.60 \\
\hline $\mathrm{Rb}$ & 4.00 & 10.00 & 6.00 & 23.0 & 5.00 & 66.0 & 263 & 255 \\
\hline $\mathrm{Sr}$ & 24.0 & 31.0 & 12.0 & 55.0 & 62.0 & 93.0 & 973 & 1076 \\
\hline Y & 1.50 & 2.60 & 2.30 & 2.10 & 1.90 & 4.20 & 22.3 & 26.1 \\
\hline $\mathrm{Zr}$ & 4.00 & 7.00 & 4.00 & 8.00 & 5.00 & 26.0 & 357 & 423 \\
\hline $\mathrm{Nb}$ & 0.1 & 0.7 & 0.1 & 0.6 & 0.4 & 2.6 & 53.4 & 73.2 \\
\hline Cs & $<0.2$ & $<0.2$ & $<0.2$ & $<0.2$ & 0.2 & 3.2 & 14.2 & 17.0 \\
\hline $\mathrm{Ba}$ & 23.0 & 49.0 & 18.0 & 89.0 & 17.0 & 160 & 997 & 1290 \\
\hline $\mathrm{La}$ & 0.340 & 0.500 & 0.190 & 0.940 & 0.330 & 6.40 & 65.1 & 79.4 \\
\hline $\mathrm{Ce}$ & 0.630 & 1.07 & 0.430 & 2.20 & 0.780 & 14.9 & 147 & 173 \\
\hline $\operatorname{Pr}$ & 0.120 & 0.150 & 0.070 & 0.290 & 0.120 & 1.90 & 19.3 & 22.7 \\
\hline $\mathrm{Nd}$ & 0.370 & 0.710 & 0.340 & 1.350 & 0.680 & 8.20 & 82.8 & 97.2 \\
\hline $\mathrm{Sm}$ & 0.130 & 0.250 & 0.100 & 0.350 & 0.190 & 1.64 & 15.5 & 18.6 \\
\hline $\mathrm{Eu}$ & 0.042 & 0.073 & 0.050 & 0.094 & 0.070 & 0.368 & 3.41 & 4.05 \\
\hline Gd & 0.170 & 0.320 & 0.250 & 0.380 & 0.240 & 0.960 & 9.35 & 11.4 \\
\hline $\mathrm{Tb}$ & 0.030 & 0.060 & 0.050 & 0.060 & 0.050 & 0.140 & 1.06 & 1.24 \\
\hline Dy & 0.220 & 0.440 & 0.350 & 0.370 & 0.310 & 0.780 & 4.95 & 5.97 \\
\hline Ho & 0.050 & 0.100 & 0.080 & 0.070 & 0.070 & 0.150 & 0.82 & 0.98 \\
\hline $\mathrm{Er}$ & 0.170 & 0.310 & 0.260 & 0.220 & 0.220 & 0.450 & 2.17 & 2.48 \\
\hline $\mathrm{Tm}$ & 0.027 & 0.044 & 0.040 & 0.035 & 0.033 & 0.062 & 0.279 & 0.318 \\
\hline $\mathrm{Yb}$ & 0.180 & 0.290 & 0.260 & 0.230 & 0.220 & 0.400 & 1.66 & 1.94 \\
\hline Lu & 0.028 & 0.046 & 0.042 & 0.035 & 0.034 & 0.067 & 0.231 & 0.268 \\
\hline $\mathrm{Hf}$ & $<0.1$ & $<0.1$ & $<0.1$ & 0.1 & $<0.1$ & 0.500 & 7.60 & 11.00 \\
\hline Ta & 0.006 & 0.009 & 0.005 & 0.008 & 0.007 & 0.150 & 3.70 & 4.41 \\
\hline W & $<0.5$ & $<0.5$ & $<0.5$ & $<0.5$ & $<0.5$ & 2.10 & 3.30 & 7.00 \\
\hline $\mathrm{Tl}$ & $<0.05$ & $<0.05$ & $<0.05$ & $<0.05$ & $<0.05$ & 0.060 & 0.520 & 0.420 \\
\hline $\mathrm{Pb}$ & 7.00 & 7.00 & 4.50 & 12.0 & 4.50 & 4.50 & 31.0 & 35.0 \\
\hline $\mathrm{Bi}$ & $<0.1$ & $<0.1$ & $<0.1$ & $<0.1$ & $<0.1$ & $<0.1$ & 0.100 & 0.100 \\
\hline Th & 0.240 & 0.610 & 0.060 & 0.640 & 0.450 & 3.09 & 42.7 & 53.0 \\
\hline $\mathrm{U}$ & 0.750 & 0.670 & 0.620 & 0.650 & 0.460 & 0.690 & 10.7 & 12.8 \\
\hline $\mathrm{Ti}$ & 336 & 534 & 468 & 588 & 408 & 1349 & 11055 & 13789 \\
\hline \#Mg & 91.6 & 91.7 & 91.8 & 92.0 & 92.0 & 90.0 & 81.4 & 75.0 \\
\hline
\end{tabular}

2010), avoiding strong host melt interactions. Nevertheless, the small size and especially narrow thickness $(<1 \mathrm{~cm})$ of tabular shaped MVM lherzolite xenoliths may explain the extension of their host-melt reaction zones. This laminar shape could be due to the original foliated structure of the lithospheric mantle beneath central Spain (Puelles et al., 2016).

\subsection{Partial melting and nature of lithospheric mantle sources}

Major element compositions of mafic primary mineral phases, particularly the $\mathrm{MgO}$ and $\mathrm{Al}_{2} \mathrm{O}_{3}$ pyroxene contents and the spinel $\mathrm{Cr} \#$ are indicators of partial melting processes in the mantle (Bonadiman and Coltorti, 2011; Norman, 1998; Upton et al., 2011). Thus, in a $\mathrm{MgO}-\mathrm{Al}_{2} \mathrm{O}_{3}$ diagram, clinopyroxene and orthopyroxene compositions from the MVM lherzolites (Fig. 12a and $b$ ) plot at different melting degree, with the group-1 xenoliths displaying higher values (10-15\%) compared to group-2 (around $5 \%$ partial melting), despite having less depleted REE patterns. The slightly enriched LREE pattern of clinopyroxenes of the MVM group-1 lherzolites might be explained by later metasomatic imprint, as discussed below. Moreover, spinel from the MVM group2 lherzolites display lower $\mathrm{Cr} \#$ compared to the group- 1 for similar $\mathrm{TiO}_{2}$ content, which also indicates different partial melting degrees, in the same way as that of pyroxene chemistry (i.e., $5 \%$ and $10 \%$, respectively) (Fig. 12c). A similar melt depletion degree in the MVM peridotites is also inferred from the OSMA diagram between $\mathrm{Cr} \#$ in spinel and $\mathrm{Mg \#}$ in associated olivine (Fig. 5), being slightly higher in the group-1 lherzolites. Estimated melting degrees based on 

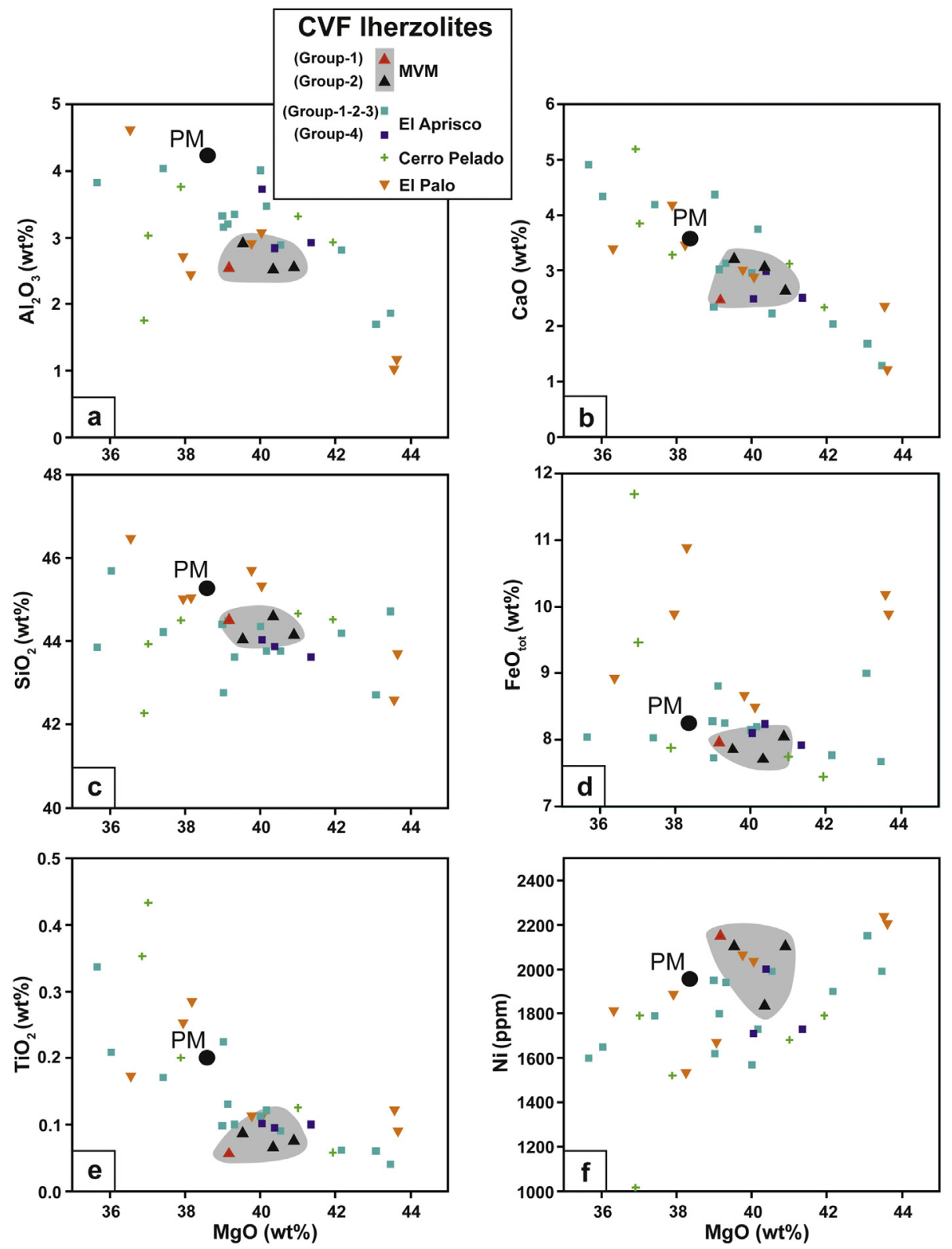

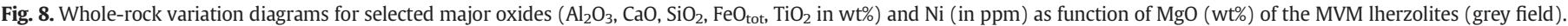

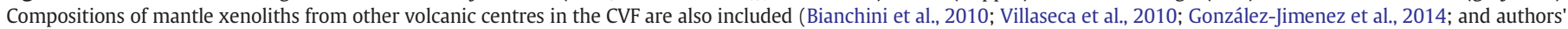
unpublished data). The composition of primitive mantle (PM) (McDonough and Sun, 1995) is represented by a filled circle.

major element mineral compositions of MVM lherzolites are within the range of values found in other CVF xenolith suites (Andía et al., 2018; Villaseca et al., 2010).

Depletion processes could be also modelled through mineral trace elements. Thus, the partial melting degree of a mantle protolith is also estimated by their clinopyroxene HREE-Y contents, good indicators of the extent of melt extraction (Bedini and Bodinier, 1999; Norman, 1998). MVM lherzolites have primary clinopyroxene Y-Yb contents that yield higher melting degrees for the group-1 (up to 9\%, Supplementary Fig. S3) than for group-2 lherzolites. Even so, this moderate partial melting degree range ( 5 to $10 \%$ ) contrasts with data from other Iberian mantle xenolith suites (Fig. 5). In the Olot volcanic field, lherzolite xenoliths yield modelled melting fractions up to $17 \%$ and even higher when involving harzburgite types (up to 30-40\%) (Fig. 5) (Bianchini et al., 2007; Galán et al., 2008). In the Tallante volcanic centre (SE Spain), the presence of harzburgite and orthopyroxene-rich lherzolite xenoliths also suggest a large degree of partial melting of its sampled lithospheric mantle, illustrated by their high spinel $\mathrm{Cr} \#$, which defines a more residual mantle xenolith suite (Fig. 5) (Avanzinelli et al., 2020; Beccaluva et al., 2004; Shimizu et al., 2004). The low $\mathrm{Cr}$, Ni and Mg contents of mafic minerals of the MVM mantle xenoliths is also indicative of a more fertile character of the lithospheric mantle beneath central Spain when compared to mantle xenolith suites of the rest of alkaline Iberian volcanic fields.

The LREE-depleted signature of the MVM group-2 lherzolites can be an original MORB type signature, with no later metasomatic interactions, as discussed below. This mantle protolith has only been mentioned in the group- 4 of the El Aprisco xenolith suite (Villaseca et al., 2010). Nevertheless, the recorded MVM clinopyroxene Sr-Nd isotopic values in a concentrate of lherzolite primary crystals imply an isotopic composition different to that previously obtained in Calatrava xenolith suites (Fig. 10). Moreover, despite the Sr-Nd isotopic differences between the MVM clinopyroxene separate and the El Aprisco group-4 lherzolites, these two suites plot away from the chemical compositional 

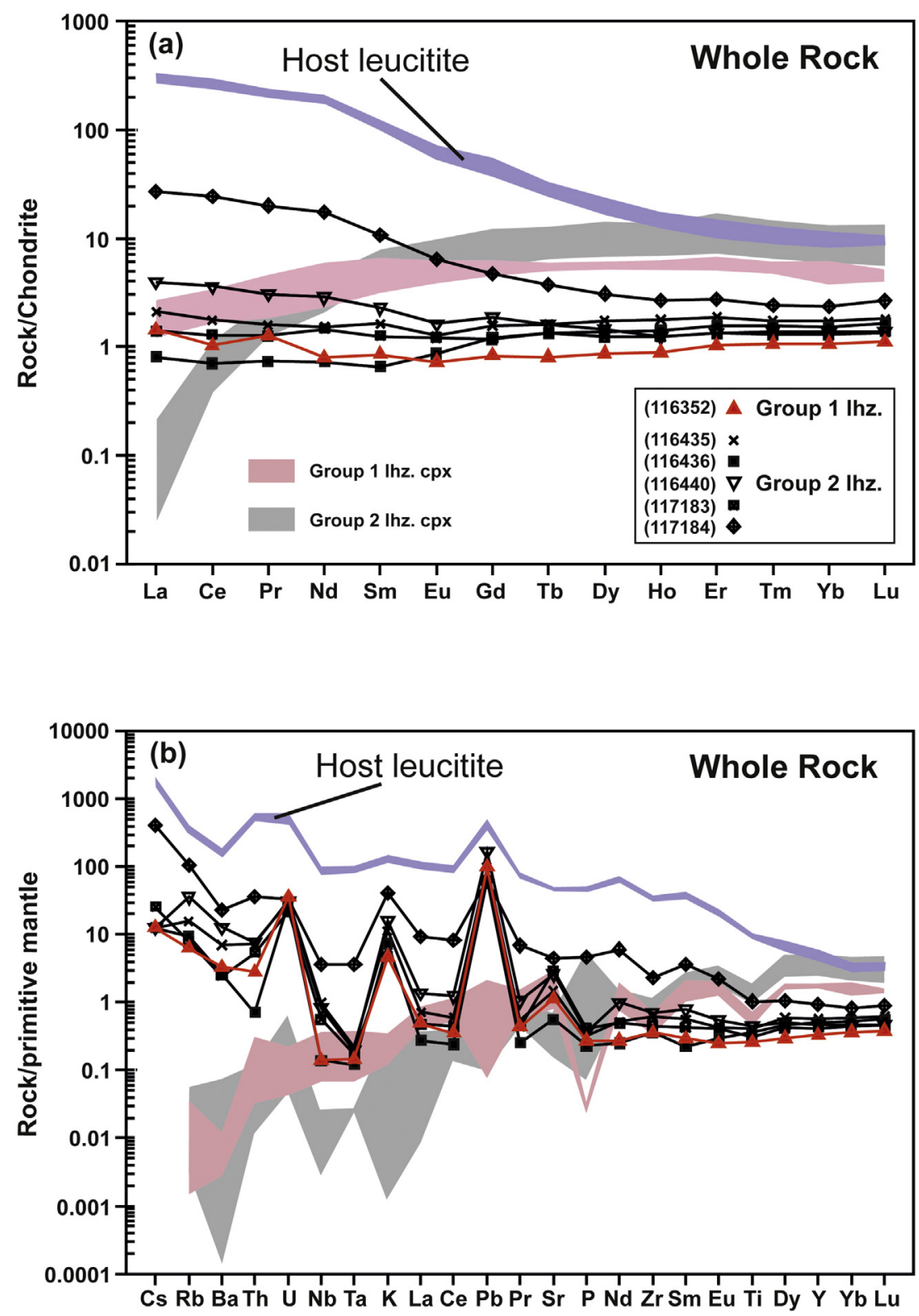

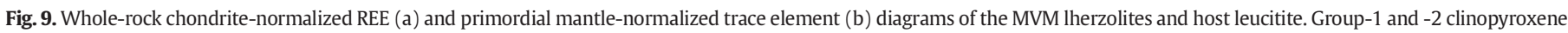
compositional fields from the MVM lherzolites are also included for comparison. Normalizing values from McDonough and Sun (1995).

Table 6

( $\mathrm{Sr}-\mathrm{Nd}$ ) isotope composition of the Morrón de Villamayor mantle xenoliths and host leucitite.

\begin{tabular}{|c|c|c|c|c|c|c|c|c|c|}
\hline Sample & & $\left({ }^{87} \mathrm{Sr} /{ }^{86} \mathrm{Sr}\right)_{\mathrm{m}}$ & 1SE & $\left({ }^{87} \mathrm{Sr} /{ }^{86} \mathrm{Sr}\right)_{0}$ & $\varepsilon \mathrm{Sr}_{0}$ & $\left({ }^{143} \mathrm{Nd} /{ }^{144} \mathrm{Nd}\right)_{\mathrm{m}}$ & 1SE & $\left({ }^{143} \mathrm{Nd} /{ }^{144} \mathrm{Nd}\right)_{0}$ & $\varepsilon \mathrm{Nd}_{0}$ \\
\hline \multicolumn{10}{|c|}{ Lherzolite xenoliths } \\
\hline 116352 & Whole rock & 0.706389 & 0.000004 & 0.706348 & 26.9 & 0.512725 & 0.000005 & 0.512716 & 1.8 \\
\hline 116428 & Whole rock & 0.706504 & 0.000003 & 0.706401 & 28.5 & 0.512425 & 0.000001 & 0.512418 & -4.0 \\
\hline Cpx 116429 & Primary clinopyroxene crystals & 0.706105 & 0.000003 & 0.706104 & 22.9 & 0.512845 & 0.000004 & 0.512830 & 4.2 \\
\hline 116435 & Whole rock & 0.706562 & 0.000003 & 0.706483 & 29.4 & 0.512738 & 0.000002 & 0.512730 & 2.1 \\
\hline 116436 & Whole rock & 0.707101 & 0.000003 & 0.706978 & 37.0 & 0.512870 & 0.000005 & 0.512863 & 4.7 \\
\hline 116440 & Whole rock & 0.706740 & 0.000003 & 0.706637 & 31.9 & 0.512444 & 0.000001 & 0.512438 & -3.6 \\
\hline \multicolumn{10}{|l|}{ Host leucitite } \\
\hline 114409 & Whole rock & 0.706553 & 0.000003 & 0.706487 & 28.3 & 0.512394 & 0.000001 & 0.512389 & -4.7 \\
\hline 117189 & Whole rock & 0.706960 & 0.000003 & 0.706902 & 34.2 & 0.512381 & 0.000003 & 0.512376 & -5.0 \\
\hline
\end{tabular}

Initial isotopic ratios calculated at $7 \mathrm{Ma}$

* Clinopyroxene separate. 


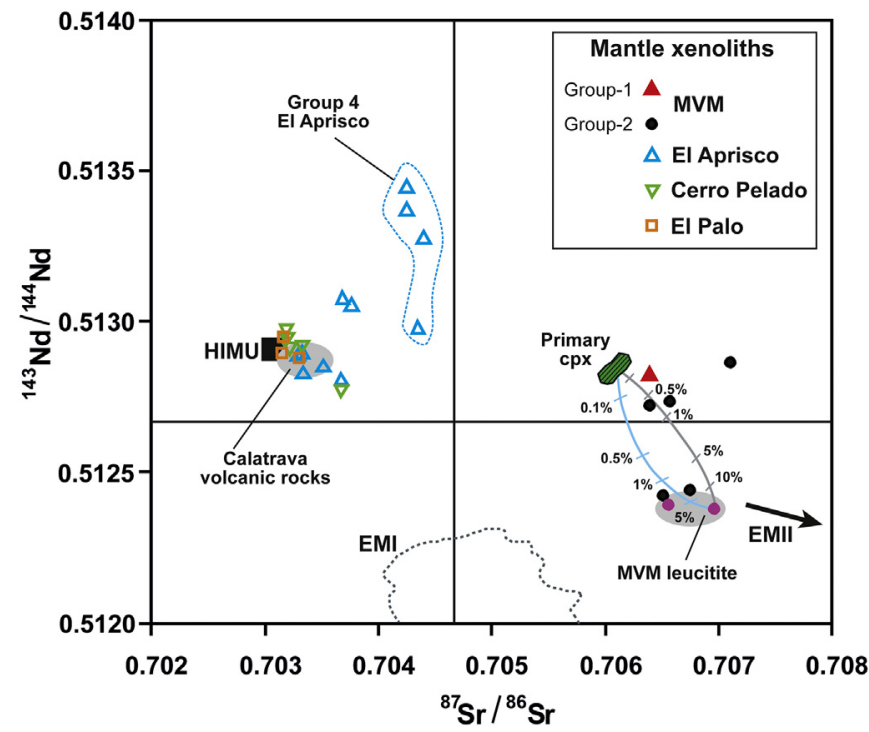

Fig. 10. Initial ${ }^{143} \mathrm{Nd} /{ }^{144} \mathrm{Nd}$ vs. ${ }^{87} \mathrm{Sr} /{ }^{86} \mathrm{Sr}$ ratios of the MVM mantle xenoliths and their host leucitites compared to other Calatrava mantle xenolith suites (Bianchini et al., 2010; Villaseca et al., 2010; González-Jimenez et al., 2014; and authors' unpublished data). Volcanic rocks from the CVF (López Ruiz et al., 2002; Villaseca et al., 2020) and mantle end members (HIMU, EMI and EMII) (Zindler and Hart, 1986) are also plotted. Two isotope mixing lines between the MVM primary clinopyroxene separate and the leucitite 117,189 (crystal-poor, not porphyritic sample) poles are marked for two different $\mathrm{Sr} / \mathrm{Nd}$ ratios (32 and 6, respectively). Note that tick marks above $5 \%$ or $10 \%$ (depending of the mixing model) of leucitite contamination are not included due to its overlapping with the leucitite pole composition due to the extremely high $\mathrm{Sr}$ and $\mathrm{Nd}$ contents of the ultrapotassic melt (1076 and 97.2 ppm, respectively, Table 5).

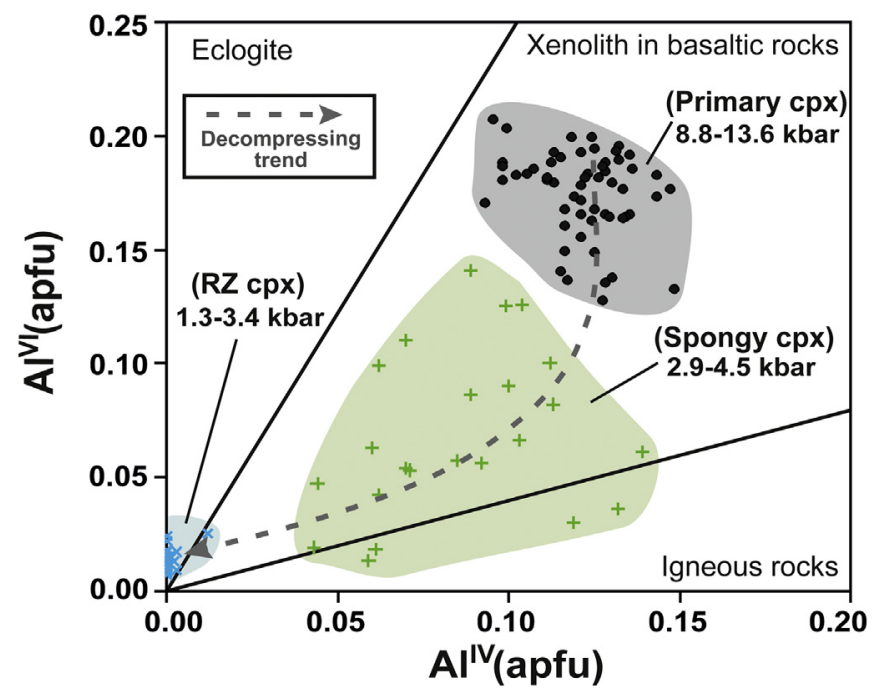

Fig. 11. $\mathrm{Al}^{\mathrm{IV}}$ vs. $\mathrm{Al}^{\mathrm{VI}}$ (apfu) diagram showing primary and secondary clinopyroxene (spongy and small neoblasts from reaction zones) compositions from the MVM lherzolites. The boundary lines separating eclogite, xenolith in basaltic rocks and igneous rocks fields are from Aoki and Kushiro (1986).

field of the HIMU-source, as the rest of studied CVF xenolith suites (Bianchini et al., 2010; Villaseca et al., 2010). In addition, MVM lherzolites (whole-rock data) show evidence of contamination, as they plot toward the narrow isotopic field of the host leucitites (e.g., sample 116440, Table 6), suggesting that most of the MVM samples (either from group- 1 or -2 ) reflect minor mixing processes with the leucitite host magma. It should be noted that the high $\mathrm{Sr}$ and $\mathrm{Nd}$ contents of the host K-rich melt (1076 and $97.2 \mathrm{ppm}$, respectively), compared to those of MVM lherzolites (12 and $0.37 \mathrm{ppm}$, respectively) (see caption to Fig. 10), cause a remarkable change in mantle isotopic ratios, even at low mixing degrees ( $<5 \%$ of leucitite contamination) (Fig. 10).

The isotopic composition of the MVM clinopyroxene separate suggests the presence of an enriched isotope mantle source beneath the Calatrava area intermediate between DMM and EMII components. It is worth noting that the EMII isotopic mantle composition was sampled in the Central Iberian Zone by basic magmatism previous to this Cenozoic alkaline intraplate CVF, during orogenic Variscan events and later Early Jurassic tholeiitic intrusions related to the opening of the central Atlantic Ocean (e.g., Villaseca et al., 2004). The existence of EMII mantle sources in the lithospheric mantle beneath central Spain should be a common feature, even if it has not been yet recorded in other studies on xenolith suites from the CVF.

\subsection{A low temperature lithospheric mantle}

Lherzolites from the MVM display markedly lower equilibration temperatures than those previously estimated in the Calatrava mantle xenolith suites (Andía et al., 2018; Bianchini et al., 2010; Villaseca et al., 2010). Importantly, the MVM geothermobarometric data plot along the geotherm of Central Iberia estimated by Jiménez-Díaz et al. (2012) (Fig. 5). The MVM volcanic centre is the only edifice generated during the first ultrapotassic magmatic stage in the CVF, when lithospheric mantle of central Iberia had not yet been heated by the later widespread Na-rich alkaline magmatism of the CVF. The second CVF magmatic stage generated hundreds of volcanic centres suggesting a significant local magma infiltration and a high thermal impact into the subcontinental lithospheric mantle of central Spain. The xenolith suite more chemically similar to the MVM lherzolites is the El Aprisco group-4 lherzolites, which display slightly higher equilibration temperatures and pressures, but also approaching the Central Iberian geotherm (Fig. 5). The El Aprisco volcanic centre belongs to the second Na-rich alkaline magmatism (with an estimated age of $2.8 \mathrm{Ma}$, Villaseca et al., 2019a), but this similarity of group- 4 xenoliths with depleted MVM lherzolites indicate that these two Calatrava magmas sampled low- $T$ lithospheric mantle levels with different compositional nature (either originally or by metasomatic interaction), as indicated by the different isotopic signatures of both xenolith suites (Fig. 10).

\subsection{Cryptic metasomatic signatures}

The two MVM lherzolite groups suggest different types of metasomatic agents and/or variable effects of percolating melts within them. The slight enrichment in LREE and other trace elements of clinopyroxene from the MVM group-1 lherzolites cannot be explained by partial melting processes and therefore may have originated by metasomatic interactions. In contrast, the LREE-depleted signature of MVM group-2 lherzolites can be an original MORB type signature, with no clear evidence of metasomatic interactions (Fig. 7a) (McDonough and Sun, 1995). Clinopyroxenes from the MVM group-1 show a slightly LREE-enrichment compared to group-2 lherzolites, but all studied MVM lherzolites display LREE-depleted signatures in comparison to most of the CVF mantle xenoliths (González-Jimenez et al., 2014; Villaseca et al., 2010). This slight LREE enrichment suggests a metasomatic overprint with different effect in the group-1 mantle xenoliths. Only the most incompatible LREE have been affected (La, Ce, Pr), which could indicate that the group-1 lherzolites were located far enough from percolating metasomatic agents, modifying only the most incompatible trace element concentrations (Ionov et al., 2002). One of these LREE enriched lherzolites (sample 116442) shows clinopyroxene with a low Ti/Eu ratio (Fig. 13) and HREE content suggesting a higher partial melting degree than depleted group-2 lherzolites (Supplementary Fig. S3). Thus, the group-1 lherzolites could have been harzburgitic in nature prior to some LREE enriched metasomatic event (Hill et al., 2011; Le Roux et al., 2007). 

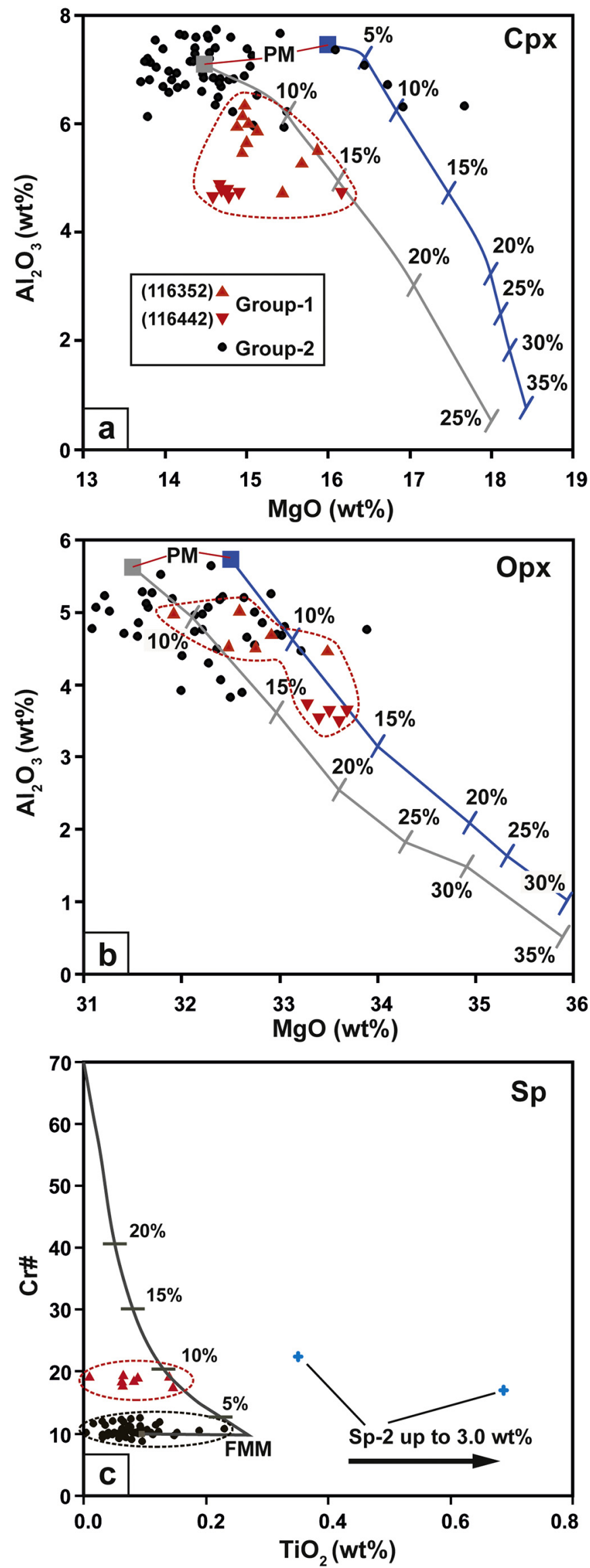
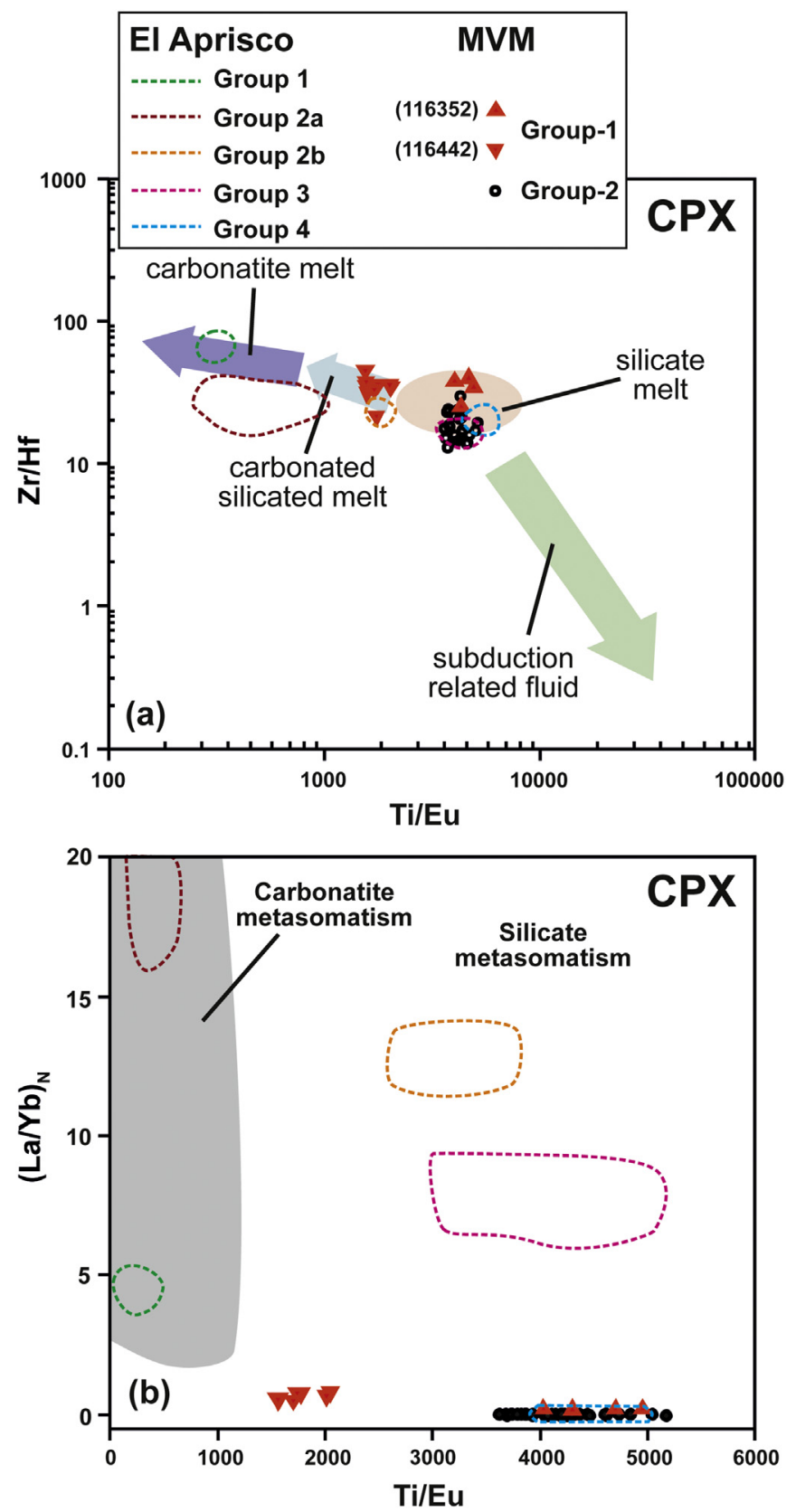

Fig. 13. Clinopyroxene composition of the MVM lherzolite groups compared to those from El Aprisco mantle xenoliths groups (González-Jimenez et al., 2014; Villaseca et al., 2019a).

(a) $\mathrm{Ti} / \mathrm{Eu} \mathrm{vs}$. $\mathrm{Zr} / \mathrm{Hf}$ ratios with trends for different metasomatizing agents from UenverThiele et al. (2017); (b) Ti/Eu vs. La/Yb chondrite-normalized (N) ratios and fields for carbonatite (shaded area) and silicate melt metasomatism adapted from Coltorti et al. (1999).

Clinopyroxene compositions of group-1 lherzolites suggest slightly different metasomatic agents. The clinopyroxene from 116352 lherzolite has similar Ti/Eu and $\mathrm{Zr} / \mathrm{Hf}$ ratios than those from the MVM

Fig. 12. Partial melting trends of Bonadiman and Coltorti (2011) (grey) and Upton et al. (2011) (blue) on pyroxene composition diagrams (a) and (b). (c) $\mathrm{TiO}_{2}$ vs. $\mathrm{Cr} \#$ compositional variation of spinel from the MVM lherzolites compared to the partial melting trend of a fertile MORB mantle (FMM) from Arai (1992). Secondary spinel (Sp2) composition plots outside the partial melting trend (see black arrow). 
group-2 lherzolites, indicating that they have undergone a silicate melt metasomatic event, but without a subduction component (Fig. 13a). The clinopyroxene from 116442 lherzolite shows the lowest Ti/Eu ratio, plotting closer to the compositional range of carbonatitic metasomatism (Fig. 12b). However, its Ti/Eu $>1500$ and $(\mathrm{La} / \mathrm{Yb})_{\mathrm{N}}$ ratios $<3-4$ might be better related to carbonated-rich alkali silicate melt metasomatism (Coltorti et al., 1999). The MVM leucitite is rejected as metasomatic agent due to the lack of potassium positive anomaly in primary clinopyroxene of 116442 lherzolite (Fig. 7c and d). Therefore, the compositional features of the MVM group-1 lherzolites suggest that they were refertilized by different melts: (1) an alkaline silicate melt for 116352 lherzolite; and (2) a carbonate-rich alkaline silicate melt for 116442 lherzolite (Fig. 13a). Refertilization of fertile lherzolitic composition is incompatible with the high spinel $\mathrm{Cr}$ content and the relatively Mg-rich olivine of these samples, more typical of harzburgite or clinopyroxene-poor lherzolites. This process may have occurred in the latest stages of a partial melting event, or later, by interaction with percolating melt within the peridotite matrix (e.g., Uenver-Thiele et al., 2017).

Calculated melt compositions in equilibrium with clinopyroxenes from the MVM group-1 lherzolites show an alkaline affinity that has not been sampled in analysed CVF rocks (Fig. 14). The estimated metasomatic melt of lherzolite 116442 shows higher LREE and lower HREE contents than the melt equilibrated with the other group-1 lherzolite
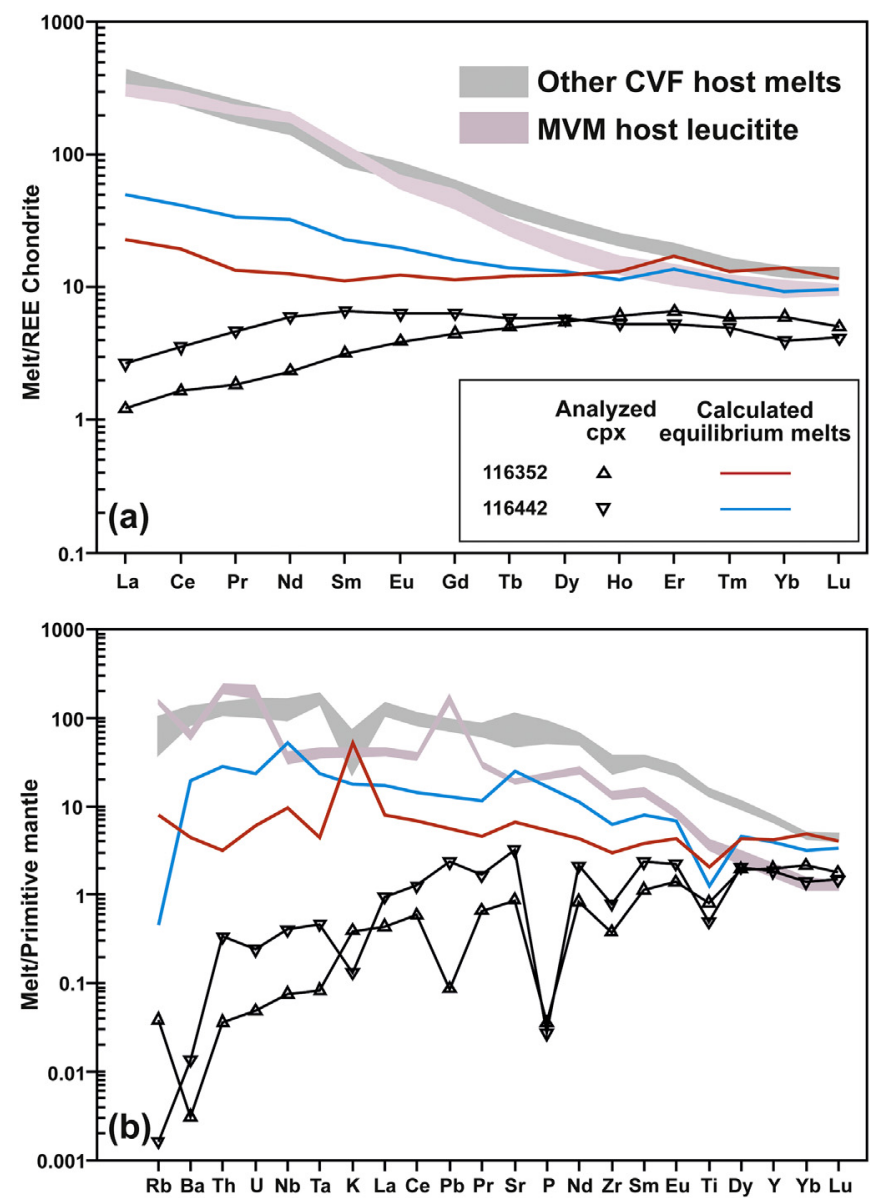

Fig. 14. Calculated melts in equilibrium with averaged clinopyroxene from the MVM group-1 lherzolites. (a) Chondrite-normalized REE and (b) primordial mantlenormalized trace element patterns. Host leucitite and representative CVF host melts (Cebriá and López Ruiz, 1995; Villaseca et al., 2020) are also included for comparison. Melt compositions have been calculated using cpx-basaltic melt partition coefficients (Hart and Dunn, 1993; Zack and Brumm, 1998), except for Rb (Foley et al., 1996). Normalizing values for chondrite and primitive mantle from McDonough and Sun (1995).
116352 (Fig. 14a). The slight LREE upward pattern and the slightly positive Nb-Ta anomaly in PM-normalized diagrams (Fig. 14b) suggest an alkaline melt as a metasomatic agent. Although the estimated melt is not similar to Calatrava host alkaline melts, this could be the consequence of a minor melt percolation or other spatial parameters involved in this process (Ionov et al., 2002). However, in chondrite-normalized diagrams, the estimated composition of the melt in equilibrium with 116352 clinopyroxene displays a flatter REE pattern than 116442, different to the trace element patterns shown by host ultrabasic Calatrava alkaline melts (Fig. 14).

Major and trace element composition of clinopyroxene from the MVM lherzolites are similar to those from the El Aprisco group-4 lherzolites (González-Jimenez et al., 2014) (Fig. 6), especially when comparing with clinopyroxene from the depleted MVM group-2 lherzolites (Fig. 13a and b). The group- 4 of the El Aprisco xenoliths have been interpreted as the result of subduction-related silicate melt metasomatism (González-Jimenez et al., 2014), but this effect is not recognized in the MVM samples with the current data.

In summary, the comparison to previously studied Calatrava mantle xenolith suites from Na-rich alkaline volcanoes, the MVM peridotite xenoliths show a significant Sr-LREE-HFSE-depleted composition. The depleted MVM clinopyroxene trace element composition contrasts with the marked LREE-Th-U-Nb-Ta-Pb enrichment of those from the El Aprisco mantle xenolith groups, except for the group-4, which is similar to MVM group-2 clinopyroxene compositions (Fig. 7a and c). On the other hand, the Cerro Pelado and El Palo volcanic centres contain TiFe-rich lherzolite/wehrlite xenoliths, interpreted as the result of largescale mantle refertilization induced by the reactive percolation of silica-undersaturated melts similar in composition to their host Narich Calatrava magmatism (Villaseca et al., 2010). Nevertheless, although clinopyroxene composition from the MVM group-1 lherzolite 116442 suggests interaction with an alkaline silicate melt, its slight LREE enrichment is markedly lower than the Cerro Pelado and El Palo lherzolithic clinopyroxene compositions (Fig. 7b and d) (Bianchini et al., 2010; Villaseca et al., 2010), indicating different alkaline metasomatic agents to those affecting the MVM xenoliths.

\section{Conclusions}

1. Studied lherzolites from the MVM volcano display a strong xenolithhost melt interaction toward xenolith contacts, developing reaction zones and spongy rims on primary minerals (clinopyroxene and spinel). Secondary mineral chemistry records a K, Th, U, Pb and LREE rich values resembling those of the host leucitite. Whole rock analyses and Sr-Nd isotopic composition also show variable contamination of some samples with the host melt during volcanic transport within the high-temperature host melt.

2. The MVM mantle xenoliths consist exclusively of spinel-bearing lherzolites that can be divided in two groups according to chondrite and PM-normalized diagrams: group-1 lherzolites show flat REE patterns, whereas group-2 lherzolites exhibit LREE-depleted patterns, like N-MORB sources. The MVM lherzolites (based on data from a primary clinopyroxene concentrate) show originally high $\mathrm{Sr}$ $\left({ }^{87} \mathrm{Sr} /{ }^{86} \mathrm{Sr}=0.706104\right)$ and intermediate $\mathrm{Nd}\left({ }^{143} \mathrm{Nd} /{ }^{144} \mathrm{Nd}=\right.$ 0.512830 ) initial radiogenic ratios, a singular isotopic composition absent elsewhere in xenolith suites of the Calatrava Volcanic Field. This implies a direct sampling of an enriched isotope mantle pole in the Calatrava area (of EMII affinity). This isotopic signature is, nevertheless, very common in the long-lasting Central Iberian basic magmatism previous to this Cenozoic alkaline intraplate volcanism.

3. The sampled lithospheric mantle from the Morrón de Villamayor volcano shows similar pressure (depth range) conditions than the rest of studied Calatrava mantle xenoliths, but lower equilibration temperatures. The MVM is the only volcanic centre generated during the first ultrapotassic event of the CVF, suggesting that at this time the lithospheric mantle of central Iberia had not yet underwent 
significant thermal input, expected during the second widespread sodic volcanic stage, that generated hundreds of volcanic centres, and therefore promoting a higher heating of broad mantle sectors.

4. The slightly LREE enrichment shown by group- 1 lherzolites suggest a refertilization by a metasomatic event. Each analysed group- 1 lherzolite suggests a different metasomatic interaction: (1) a silicate melt for 116352 lherzolite; (2) an alkaline silicate melt for 116442 lherzolite. The subcontinental lithospheric mantle of central Spain has undergone various alkaline metasomatic events before the Calatrava magmatism and it is likely that some of them could have refertilized these lherzolites. Moreover, group-1 lherzolites define a more residual lithospheric mantle composition than group-2. The MVM lherzolite xenoliths have a more Sr-LREE-HFSE-depleted composition compared to previously studied xenolith suites expatriated during the widespread second magmatic stage (Na-rich) of the Calatrava Field. In this way, MVM lherzolites do not show Fe-Ti enrichment as Cerro Pelado and El Palo xenolith suites. The MVM lithospheric mantle has not recorded any carbonatite enrichment signature as is the case in some El Aprisco xenolith suites. The MVM lithospheric mantle is only similar to that sampled within El Aprisco group-4 lherzolites. In conclusion, MVM xenoliths are less metasomatised than any other CVF xenolith suite.

Supplementary data to this article can be found online at https://doi. org/10.1016/j.lithos.2020.105830.

\section{Declaration of Competing Interest}

The authors declare that they have no known competing financial interests or personal relationships that could have appeared to influence the work reported in this paper.

\section{Acknowledgements}

We specially thank Alfredo Fernández Larios for his assistance with the electron microprobe analyses in the Centro Nacional de Microscopía Electrónica (UCM). Manuel J. Román Alpiste and Carlos J. Garrido are thanked for their assistance with the LA-ICP-MS of the Instituto Andaluz de Ciencias de la Tierra (CSIC) from Granada. Thanks also to Emma Losantos for her corrections and comments to the text. We thank the revision effort made by Suzette Timmerman (guest editor) that have considerably increased the quality of the original ms. We also greatly appreciate the comments and revision made by Michel Grégoire and Riccardo Avanzinelli on a previous version of the manuscript. This work is included in the objectives and supported by the CGL2016-78796 project of the Spanish Ministerio de Ciencia e Innovación (MICINN), and the UCM 910492 group.

\section{References}

Ackerman, L., Mahlen, N., Jelínek, E., Medaris Jr., G., Ulrych, J., Strnad, L., Mihaljevic, M., 2007. Geochemistry and evolution of subcontinental lithospheric mantle in Central Europe: evidence from peridotite xenoliths of the Kozákov volcano, Czech Republic. J. Petrol. 48, 2235-2260.

Albaréde, F., 1995. Introduction to Geochemical Modelling. Cambridge University Press, Cambridge.

Ancochea, E., 1982. Evolución Especial y Temporal del Volcanismo Reciente de España Central. PhD Thesis. Complutense University, Madrid.

Ancochea, E., 2004. La región volcánica del Campo de Calatrava. In: Vera, J.A. (Ed.), Geología de España. SGE-IGME, Madrid, pp. 676-677.

Ancochea, E., Brändle, J.L., 1982. Alineaciones de volcanes en la región volcánica central española. Rev. Geofísica 38, 133-138.

Ancochea, E., Nixon, P.H., 1987. Xenoliths in the Iberian península. In: Nixon, P.H. (Ed.), Mantle Xenoliths. Wiley, Chichester, pp. 119-124.

Andía, J., Villaseca, C., Pérez-Soba, C., 2018. Mineralogical characterization of peridotite xenoliths from the Los Tormos volcano (Calatrava volcanic field). Geogaceta 63, 99-102.

Andía, J.R., 2017. Caracterización de los xenolitos peridotíticos del volcán Los Tormos (Pozuelo de Calatrava, Ciudad Real). Master thesis. Universidad Complutense.

Aoki, K., Kushiro, I., 1986. Some clinopyroxenes from ultramafic inclusions in Dreiser Weiher, Eifel. Contrib. Mineral. Petrol. 18, 326-337.
Arai, S., 1992. Chemistry of chromian spinel in volcanic rocks as a potential guide to magma chemistry. Mineral. Mag. 56, 173-184.

Arai, S., 1994. Characterization of spinel peridotites by olivine-spinel compositional relationships: review and interpretation. Chem. Geol. 113, 191-204.

Avanzinelli, R., Bianchini, G., Tiepolo, M., Jasim, A., Natalia, C., Braschi, E., Dallai, L., Beccaluva, L., Conticelli, S., 2020. Subduction-related hybridization of the lithospheric mantle revealed by trace element and $\mathrm{Sr}-\mathrm{Nd}-\mathrm{Pb}$ isotopic data in composite xenoliths from Tallante (Betic Cordillera, Spain). Lithos 352-353.

Beccaluva, L., Bianchini, G., Bonadiman, C., Siena, F., Vaccaro, C., 2004. Coexisting anorogenic and subduction-related metasomatism in mantle xenoliths from the Betic Cordillera (southern Spain). Lithos 75, 67-87.

Bedini, R.M., Bodinier, J.-L., 1999. Distribution of incompatible trace elements between the constituents of spinel peridotite xenoliths: ICP-MS data from the East African Rift. Geochim. Cosmochim. Acta 63, 3883-3900.

Bianchini, G., Beccaluva, L., Bonadiman, C., Nowell, G., Pearson, G., Siena, F., Wilson, M., 2007. Evidence of diverse depletion and metasomatic events in harzburgitelherzolite mantle xenoliths from the Iberian plate (Olot, NE Spain): implications for lithosphere accretionary processes. Lithos 94, 25-45.

Bianchini, G., Beccaluva, L., Bonadiman, C., Nowell, G.M., Pearson, D.G., Siena, F., Wilson, M., 2010. Mantle metasomatism by melts of HIMU piclogite components: New insights from Fe-lherzolite xenoliths (Calatrava Volcanic District, Central Spain). In: Coltorti, M., Downes, H., Grégoire, M., O’Reilly, S.Y. (Eds.), Petrological Evolution of the European Lithospheric Mantle. 337. Geological Society, London, Special Publications, pp. 107-124.

Bonadiman, C., Coltorti, M., 2011. Numerical modelling for peridotite phase melting trends in the $\mathrm{SiO}_{2}-\mathrm{Al}_{2} \mathrm{O}_{3}-\mathrm{FeO}-\mathrm{MgO}-\mathrm{CaO}$ system at $2 \mathrm{GPa}$. Mineral. Mag. 75, 548.

Bonadiman, C., Coltorti, M., Beccaluva, L., Siena, F., 2005. Kimberlite-like metasomatism and 'Garnet Signature' in spinel- peridotite Xenoliths from Sal, Cape Verde Archipelago: Relics of a subcontinental mantle domain within the Atlantic oceanic lithosphere? J. Petrol. 46, 2465-2493.

Bonatti, E., Michael, P.J., 1989. Mantle peridotites from continental rifts to ocean basins to subduction zones. Earth Planet. Sci. Lett. 91, 297-311.

Brey, G.P., Köhler, T., 1990. Geothermobarometry in four-phase lherzolites; II, New thermobarometers, and practical assessment of existing thermobarometers. J. Petrol. 31, 1353-1378.

Carminati, E., Lustrino, M., Doglioni, C., 2012. Geodynamic evolution of the central and western Mediterranean: tectonics vs. igneous petrology constraints. Tectonophysics 579, 173-192.

Cebriá, J.M., López Ruiz, J., 1995. Alkali basalts and leucitites in an extensional intracontinental plate setting: the late Cenozoic Calatrava Volcanic Province (Central Spain). Lithos 35, 27-46.

Cebriá, J.M., Martín-Escorza, C., López-Ruiz, J., Morán-Zenteno, D.J., Martiny, B.M., 2011. Numerical recognition of alignments in monogenetic volcanic areas: examples from the Michoacán- Guanajuato Volcanic Field in Mexico and Calatrava in Spain. J. Volcanol. Geotherm. Res. 201, 73-82.

Coltorti, M., Bonadiman, C., Hinton, R.W., Siena, F., Upton, B.G.J., 1999. Carbonatite metasomatism of the oceanic upper mantle: evidence from clinopyroxenes and glasses in ultramafic xenoliths of Grande Comore, Indian Ocean. J. Petrol. 40, 133-165.

De Vicente, G., Vegas, R., 2009. Large-scale distributed deformation controlled topography along the western Africa-Eurasia limit: tectonic constraints. Tectonophysics 474, $124-143$.

Downes, H., 2001. Formation and modification of the shallow sub-continental lithospheric mantle: a review of geochemical evidence from ultramafic xenolith suites and tectonically emplaced ultramafic massifs of western and Central Europe. J. Petrol. 42, 233-250.

Fernández, M., Marzán, I., Correia, A., Ramalho, E., 1998. Heat flow, heat production, and lithospheric thermal regimen in the Iberian Peninsula. Tectonophysics 291, 29-53.

Foley, S.F., Jackson, S.E., Fryer, B.J., Greenough, J.D., Jenner, G.A., 1996. Trace element partition coefficients for clinopyroxene and phlogopite in an alkaline lamprophyre from Newfoundland by LA-ICP-MS. Geochim. Cosmochim. Acta 60, 629-638.

Galán, G., Oliveras, V., Paterson, B.A., 2008. Types of metasomatism in mantle xenoliths enclosed in Neogene-Quaternary alkaline mafic lavas from Catalonia (NE Spain). In: Coltorti, M., Grégoire, M. (Eds.), Metasomatism in Oceanic and Continental Lithospheric Mantle. 293. Geological Society, London, Special Publications, pp. 121-153.

García Serrano, J., Villaseca, C., Pérez-Soba, C., 2019. Peridotite Xenoliths from the El Morrón de Villamayor Volcano (Calatrava Volcanic Field). Goldschmidt 2019 Abstracts, 1094

González-Jimenez, J.M., Villaseca, C., Griffin, W.L., O’Reilly, S.Y., Belousova, E., Ancochea, E. 2014. Significance of ancient sulphide PGE and Re-Os signatures in the mantle beneath Calatrava, Central Spain. Contrib. Mineral. Petrol. 168, 1047.

Granja Bruña, J.L., Vegas, R., Sentre, M.A., Muñoz-Martín, A., Sainz-Maza, S., 2015. Gravity modeling of the lithosphere in the Calatrava Volcanic Province (Spain): geodynamic implications. J. Iber. Geol. 41, 233-252.

Hart, S.R., Dunn, T., 1993. Experimental cpx/melt partitioning of 24 trace element. Contrib. Mineral. Petrol. 113, 1-8.

Herrero-Hernández, A., López-Moro, F., Gallardo-Millán, J.L., Martín-Serrano, A., GómezFernández, F., 2015. Volcanism-sedimentation interaction in the Campo de Calatrava Volcanic Field (Spain): a magnetostratigraphic and geochronological study. Int. J. Earth Sci. 104, 103-122.

Hill, E., Blundy, J.D., Wood, B.J., 2011. Clinopyroxene-melt trace element partitioning and the development of a predictive model HFSE and Sc. Contrib. Mineral. Petrol. 161, 423-438.

Humphreys, E.R., Bailey, K., Hawkesworth, C.J., Wall, F., Najorka, J., Rankin, A.H., 2010. Aragonite in olivine from Calatrava, Spain-evidence for mantle carbonatite melts from $>100$ km depth. Geology 38, 911-914. 
Ionov, D., Bodinier, J.L., Mukasa, S.B., Zanetti, A., 2002. Mechanisms and sources of mantle metasomatism: major and trace element compositions of peridotite xenoliths from Spitsbergen in the context of numerical modelling. J. Petrol. 43, 2219-2259.

Jiménez-Díaz, A., Ruiz, J., Villaseca, C., Tejero, R., Capote, R., 2012. The thermal state and strength of the lithosphere in the Spanish Central System and Tajo Basin from crustal heat production and thermal isostasy. J. Geodyn. 58, 29-37.

Le Roux, V., Bodinier, J.-L., Tommasi, A., Alard, O., Dautria, J.-M., Vauchez, A., Riches, A.J.V., 2007. The Lherz spinel lherzolite: refertilized rather than pristine mantle. Earth Planet. Sci. Lett. 259, 599-612.

Lierenfeld, M.B., Mattsson, H.B., 2015. Geochemistry and eruptive behaviour of the Finca la Nava maar volcano (Campo de Calatrava, South-Central Spain). Int. J. Earth Sci. 104, 1795-1817.

López Ruiz, J., Cebriá, J.M., Doblas, M., Oyarzun, M., Hoyos, M., Martín, C., 1993. The late Cenozoic alkaline volcanism of the Central Iberian Peninsula (Calatrava Volcanic Province, Spain): intra-plate volcanism related to extensional tectonics. J. Geol. Soc. Lond. 150, 915-922.

López Ruiz, J.L., Cebriá, J.M., Doblas, M., 2002. Cenozoic volcanism in the Iberian Peninsula. In: Gibbons, W., Moreno, T. (Eds.), The Geology of Spain. The Geological Society, London, pp. 417-438.

Lustrino, M., Wilson, M., 2007. The circum-Mediterranean anorogenic Cenozoic igneous province. Earth Sci. Rev. 81, 1-65.

Lustrino, M., Prelević, D., Agostini, S., Gaeta, M., Di Rocco, T., Stagno, V., Capizzi, L.S., 2016. Ca-rich carbonates associated with ultrabasic-ultramafic melts: Carbonatite or limestone xenoliths? A case study from the late Miocene Morrón de Villamayor volcano (Calatrava Volcanic Field, Central Spain). Geochim. Cosmochim. Acta 185, 477-497.

Marchev, P., Arai, S., Vaselli, O., Costa, F., Zanetti, A., Downes, H., 2017. Metasomatic reaction phenomena from entrainment to surface cooling: evidence from mantle peridotite xenoliths from Bulgaria. J. Petrol. 58 (3), 599-640.

Matusiak-Małek, M., Puziewicz, J., Ntaflos, T., Grégoire, M., Kukuła, A., Wojtulek, P.M., 2017. Origin and evolution of rare amphibole-bearing mantle peridotites from Wilcza Góra (SW Poland), Central Europe. Lithos 286-287, 302-323.

McDonough, W.F., Sun, S.S., 1995. The composition of the Earth. Chem. Geol. 120, 223-253.

Nimis, P., Ulmer, P., 1998. Clinopyroxene geobarometry of magmatic rocks. Part 1: an expanded structural geobarometer for anhydrous and hydrous, basic and ultrabasic systems. Contrib. Mineral. Petrol. 133, 122-135.

Norman, M.D., 1998. Melting and metasomatism in the continental lithosphere: laser ablation ICPMS analysis of minerals in spinel lherzolites from eastern Australia. Contrib. Mineral. Petrol. 130, 240-255.

O'Reilly, S.Y., Griffin, W.L., 2010. Rates of magma ascent: constraints from mantle-derived xenoliths. In: Dosseto, A., Turner, S.P., Van Orman, J.A. (Eds.), Timescales of Magmatic Processes: From Core to Atmosphere. John Wylie and Sons, Ltd, Chichester, UK, pp. 116-123.

Pan, S., Zheng, J., Yin, Z., Griffin, W.L., Xia, M., Lin, A., Zhang, H., 2018. Spongy texture in mantle clinopyroxene records decompression-induced melting. Lithos 320-321, 144-154.

Pearce, J.A., Barker, P.F., Edwards, S.J., Parkinson, I.J., Leat, P.T., 2000. Geochemistry and tectonic significance of peridotites from the South Sandwich arc-basin system, South Atlantic. Contrib. Mineral. Petrol. 139, 36-53.

Pearson, D.G., Canil, D., Shirey, S.B., 2005. Mantle samples included in volcanic rocks: xenoliths and diamonds. In: Carlson, R.W. (Ed.), The Mantle and Core. Treatise on Geochemistry 2, pp. 171-275.

Perinelli, C., Orlando, A., Conte, A.M., Armienti, P., Borrini, D., Faccini, B., Misiti, V., Coltorti, M., Grégoire, M., 2008. Metasomatism induced by alkaline magma on upper mantle of the Northern Victoria Land (Antarctica): an experimental approach. In: Coltorti, M., Grégoire, M. (Eds.), Metasomatism in Oceanic and Continental Mantle. Geological Society, London, Special Publications 293, pp. 197-221.

Puelles, P., Ábalos, B., Gil Ibarguchi, J.I., Sarrionandia, F., Carracedo, M., Fernández-Armas, S., 2016. Petrofabric and seismic properties of lithospheric mantle xenoliths from the Calatrava volcanic field (Central Spain). Tectonophysics 683, 200-215.

Reyes, J., Villaseca, C., Barbero, J., Quejido, A.J., Santos, J.F., 1997. Descripción de un método de separación de $\mathrm{Rb}, \mathrm{Sr}$, Sm y Nd en rocas silicatadas para estudios isotópicos. Congreso Ibérico de Geoquímica I 46-55.
Seghedi, I., Brändle, J.L., Szakács, A., Ancochea, E., Vaselli, O., 2002. El manto litosférico en el sureste de España: Aportaciones de los xenolitos englobados en rocas alcalinas del Mioceno-Plioceno. Geogaceta 32, 27-30.

Shaw, C.S.J., Dingwell, D.B., 2008. Experimental peridotite-melt reaction at one atmosphere: a textural and chemical study. Contrib. Mineral. Petrol. 155, 199-214.

Shaw, C.S.J., Thibault, Y., Edgar, A.D., Lloyd, F.E., 1998. Mechanisms of orthopyroxene dissolution in silica-undersaturated melts at 1 atmosphere and implications for the origin of silica-rich glass in mantle xenoliths. Contrib. Mineral. Petrol. 132, 354-370.

Shaw, C.S.J., Heidelbach, F., Dingwell, D.B., 2006. The origin of reaction textures in mantle peridotite xenoliths from Sal Island, Cape Verde: the case for "metasomatism" by the host lava. Contrib. Mineral. Petrol. 151, 681-697.

Shimizu, Y., Arai, S., Morishita, T., Yurimoto, H., Gervilla, F., 2004. Petrochemical characteristics of felsic veins in mantle xenoliths from Tallante (SE Spain): an insight into activity of silicic melt within the mantle wedge. Earth Environ. Sci. Trans. R. Soc. Edinb. 95, 265-276.

Su, B.X., Zhang, H.F., Sakyi, P.A., Zhang, Y.H., Ying, J.F., Tang, Y.J., Qin, K.Z., Xiao, Y., Zhao, X.M., Mao, Q., Ma, Y.G., 2011. The origin of spongy texture in minerals of mantle xenoliths from the Western Qinling, Central China. Contrib. Mineral. Petrol. 161, 465-482.

Uenver-Thiele, L., Woodland, A.B., Seitz, H.-M., Downes, H., Altherr, R., 2017. Metasomatic processes revealed by trace element and redox signatures of the lithospheric mantle beneath the Massif Central, France. J. Petrol. 58, 395-422.

Upton, B.G.J., Downes, H., Kirstein, L.A., Bonadiman, C., Hill, P.G., Ntaflos, T., 2011. The lithospheric mantle and lower crust-mantle relationships under Scotland: a xenolithic perspective. J. Geol. Soc. Lond. 168, 873-886.

Uysal, I., Kaliwoda, M., Karsli, O., Tarkian, M., Sadiklar, M.B., Otteley, C.J., 2007. Compositional variations as a result of partial melting and melt-peridotite interaction in an upper mantle section from the Ortaca area, SW Turkay. Can. Mineral. 45, 1471-1493.

Villaseca, C., Orejana, D., Pin, C. López García, J.-A. Andonaegui, P., 2004. Le magmatisme basique hercynien et post-hercynien du Système central espagnol: essai de charactérisation des sources mantelliques. Compt. Rendus Geosci. 336, 877-888.

Villaseca, C., Ancochea, E., Orejana, D., Jeffries, T.E., 2010. Composition and evolution of lithospheric mantle in Central Spain: inferences from peridotite xenoliths from the Cenozoic Calatrava volcanic field. In: Coltorti, M., Downes, H., Grégoire, M., O’Reilly, S.Y. (Eds.), Petrological Evolution of the European Lithospheric Mantle. Geological Society, London, Special Publications 337, pp. 125-151.

Villaseca, C., Belousova, E., Barfod, D., González-Jiménez, J.M., 2019a. Dating metasomatic events in the lithospheric mantle beneath the Calatrava volcanic field (Central Spain). Lithosphere 11, 192-208.

Villaseca, C., Dorado, O., Orejana, D., 2019b. Mineral chemistry of megacrysts and associated clinopyroxenite enclaves in the Calatrava volcanic field: crystallization processes in mantle magma chambers. J. Iber. Geol. 45, 401-426.

Villaseca, C., García Serrano, J., Pérez-Soba, C., 2019c. Metasomatism in the lithospheric mantle beneath the Calatrava volcanic field: constraints from peridotite xenoliths of the Cerro Gordo volcano. Macla 24.

Villaseca, C., García Serrano, J., Orejana, D., 2020. Pyroxenites and megacrysts from alkaline melts of the Calatrava Volcanic Field: inferences from trace element geochemistry and Sr-Nd isotope composition. Front. Earth Sci. 8, 132.

Wells, P., 1977. Pyroxene thermometry in simple and complex systems. Contrib. Mineral. Petrol. 62, 129-139.

Wood, B.J., Banno, S., 1973. Garnet-orthopyroxene and orthopyroxene-clinopyroxene relationships in simple and complex systems. Contrib. Mineral. Petrol. 42, 109-124.

Zack, T., Brumm, R., 1998. Ilmenite/liquid partition coefficients of 26 trace elements determined through ilmenite/clinopyroxene partitioning in garnet pyroxenites. In: Gurney, J.J., Gurney, J.L., Pascoe, M.D., Richardson, S.H. (Eds.), 7th International Kimberlite Conference, Capetown, pp. 986-988.

Zindler, A., Hart, S.R., 1986. Chemical geodynamics. Annu. Rev. Earth Planet. Sci. 14 493-571. 